
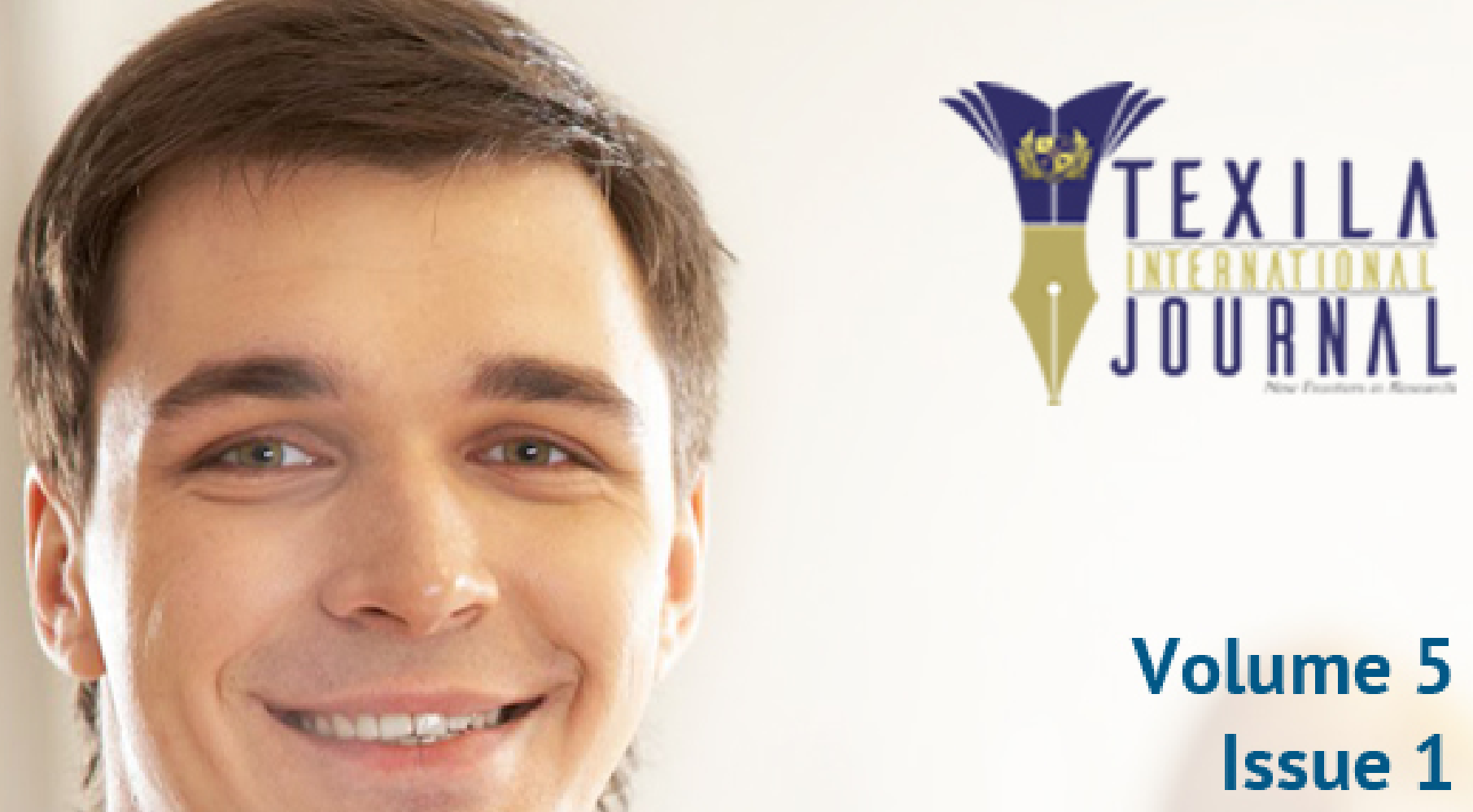

ISSN: 2520-3118

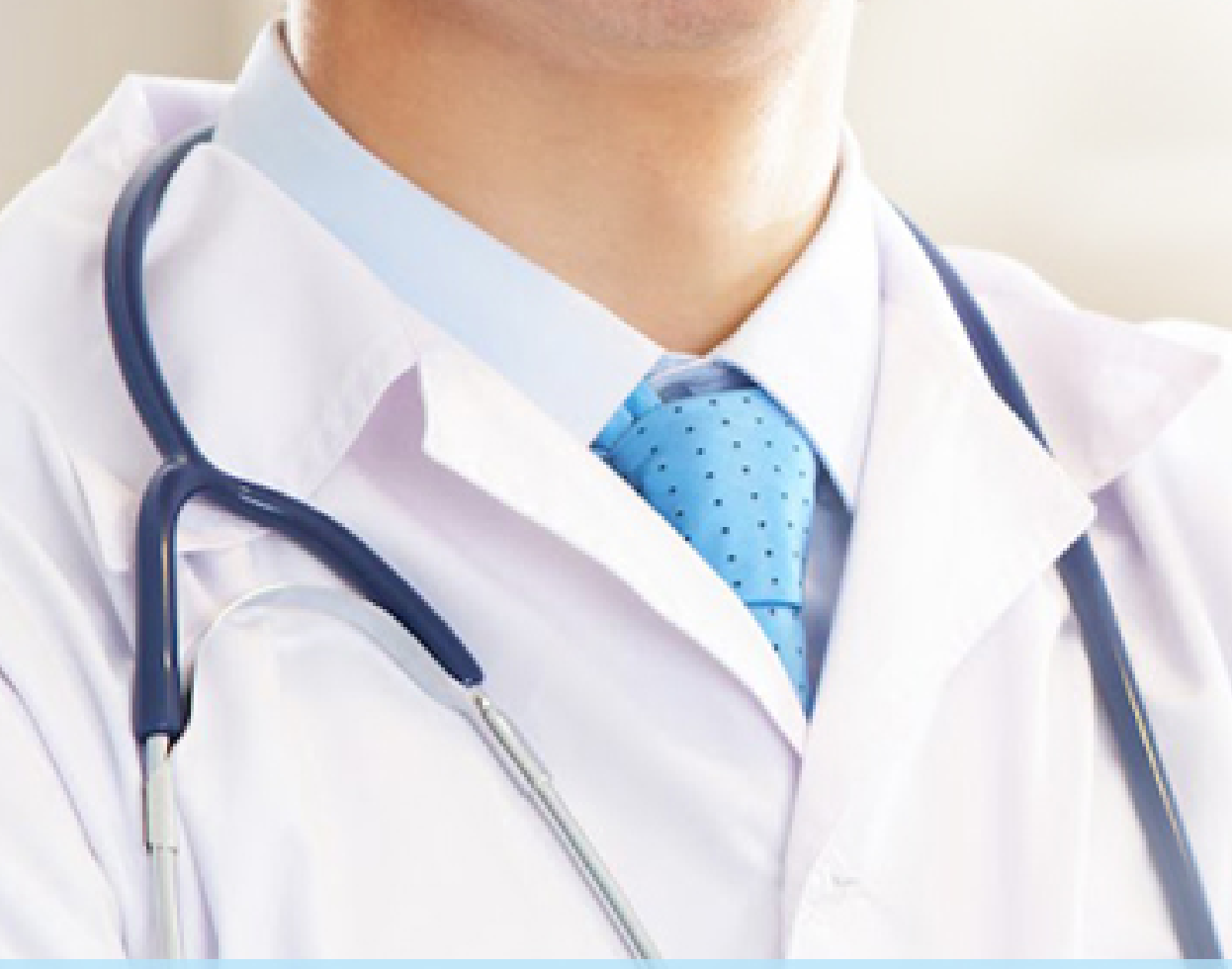

Texila International Journal Medicine 


\section{EDITORIAL POLICY}

Papers must be submitted with the understanding that they have not been published elsewhere (except in the form of an abstract or as part of a published lecture, review, or thesis) and are not currently under consideration by another journal published or any other publisher. The submitting (Corresponding) author is responsible for ensuring that the article's publication has been approved by all the other coauthors. It is also the authors' responsibility to ensure that the articles coming from a particular institution are submitted with the approval of the necessary institution. Only an acknowledgment from the editorial office officially establishes the date of receipt. It is a condition for submission of a paper that the authors permit editing of the paper for readability. All enquiries concerning the publication of accepted papers should be addressed to ejournal.assist@tau.edu.gy.

\section{PEER REVIEWERS}

Dr. Suresh Ponnusamy, Associate Professor of Medicine AIMST University, Malaysia.

Dr Sandeep T, Associate Professor, M S Ramaiah Medical College, Bangalore. 


\section{ABOUT PLAGIARISM}

Plagiarism is the use or close imitation of the language and ideas of another author and representation of them as one's own original work. Duplicate publication, sometimes called self plagiarism, occurs when an author reuses substantial parts of his or her own published work without providing the appropriate references. This can range from getting an identical paper published in multiple journals, where authors add small amounts of new data to a previous paper.

Plagiarism can be said to have clearly occurred when large chunks of text have been cut and pasted. Such manuscripts would not be considered for publication in TIJBMS Journal. But minor plagiarism without dishonest intent is relatively frequent, for example when an author reuses parts of an introduction from an earlier paper. The editors will judge any case of which they become aware (either by their own knowledge of and reading about the literature, or when alerted by referees) on its own merits.

The paper containing the plagiarism will be obviously returned back to the author's for review, but we earnestly request the authors to avoid submitting plagiarized 


\section{DISCLAIMER}

Texila International Journal of Medicine (TIJMD) make every effort to ensure the accuracy of all the information (the "Content") contained in its publications. However, the TIJMD and its agents make no representations or warranties whatsoever as to the accuracy, completeness or suitability for any purpose of the Content and disclaim all such representations and warranties whether express or implied to the maximum extent permitted by law. Any views expressed in this publication are the views of the authors and are not necessarily the views of the Editor's or Texila International Journal of Medicine. 


\section{TABLE OF CONTENT}

1 A Study of Lifestyle Factors among Patients with Diagnosis of MultiMorbidity in a Primary Care Setting in Western Nigeria

Taiwo Sogunle

2 Comparative Analysis of the in-vitro Susceptibility of Salmonella Typhi to

Chloramphenicol and Leaf Extracts of Moringa Oleifera

Oche Joseph Otorkpa

3 Acute Urinary Retention in a Young Man Secondary to Severe Dysentery: A

Case Report

Mohammad Nasir Alvi

4 Predictors of Outcome in Acute Exacerbation of Chronic Obstructive Pulmonary Disease

Suhail Neliyathodi

5 Comparison of Accommodative Facility in Tennis Players and Non Players

JayaRajini Vasanth 


\title{
A Study of Lifestyle Factors among Patients with Diagnosis of Multi- Morbidity in a Primary Care Setting in Western Nigeria
}

\author{
Article by Taiwo Sogunle \\ College of Medicine, Nigeria \\ E-mail: taiwosogunle63@gmail.com
}

\section{Background}

Multi-morbidity can be defined as the simultaneous occurrence of two or more chronic health conditions in the same person, without defining a primary disease [1, 2]. Most health systems have prominently pure single disease outlook. In these settings, multimorbidity was found to be associated with suboptimal care, increased mortality, poor quality of life and an increased demand on healthcare utilization [3,4,5,6,].

Globally, the estimated prevalence of multi-morbidity in adults is $25 \%$ [7, 8]. Most of the evidence on multi-morbidity relating to risk factors, prevalence and effects, comes from high income countries $[7,8,9]$ Few studies have been conducted in low and middle income countries $[10,11,12]$. There is therefore a need to conduct this study to contribute to the body of knowledge on multi-morbidity with the developing world in perspective as findings on multi-morbidity in developed countries cannot be utilized for formulation of management guidelines for multi-morbidity in developing countries. This is because of variations in the socioeconomic, behavioral and demographic milieu which determine the pattern and distribution of chronic diseases in these two different populations [13, 14]. Epidemiological and demographic transition in developing nations resulted in a "double burden" of infections/infestations and non - communicable diseases. This study shall therefore contribute to the much needed but lacking scientific evidence in the developing clime to dictate changes in health system management and policies to tackle these health challenges.

Available evidence indentified close relationship between lifestyle factors, chronic diseases and multi - morbidity [15 - 20]. The combination of preventive lifestyle factors has also been reported to prevent the occurrence of chronic medical conditions [21-24]. Several other studies also provided evidence on the association between individual lifestyle risk factors and multimorbidity; overweight/obesity [21, 25 - 29, 30], smoking [21, 31, 32, 33], heavy alcohol consumption [34], protective role of fruits and vegetables [35], physical inactivity [26, 39, 40] and chronic stress [36, 37, 38]. Two distinct trends emanated from these approaches. These include the association between several lifestyle facts and individual chronic diseases and the association between individual lifestyle factors and multimorbidity. It is therefore clear that the association of accumulating risk factors in the same individual with multimorbidity had not been given adequate attention even in the developed world not to talk of the developing nations [32].

The aim of the present study is to analyze the association between lifestyle factors and occurrence of multi-morbidity in the study population. We wanted to test the hypothesis that the accumulation of unhealthy lifestyle factors is associated with increased likelihood of multi-morbidity. Unhealthy lifestyle factors relates to lifestyles or behavioral characteristic or condition that increases the possibility of disease [20].

\section{Study methods}

Study design: This was a cross - sectional study.

Study setting: Participants recruited for this study were among patients attending the family practice clinics of Federal Medical Centre, Abeokuta, Ogun State, Nigeria. The Medical Centre Abeokuta provides primary, secondary and tertiary levels of care services to the people of Ogun State and neighboring states in western Nigeria. The state has a population of 3.7 million going by the 2006 population census. In this 350 - bedded hospital, 
the family practice clinic attendance was 23,010 between January to June 2014. This translates to a monthly average of 3825 and daily attendance of 127 patients. About $81.6 \%$ of clinic visits were made by revisits while the rest were new patients. Out of the revisits, $32.1 \%$ were for chronic diseases. The family practice clinic is headed by a Family Physician and trains resident doctors in Family Medicine for the two postgraduate medical colleges in Nigeria.

\section{Inclusion criteria}

Adult patients aged 25 years and above.

Willingness to participate and signing the informed consent form following understanding of the content.

\section{Exclusion criteria}

Acutely ill and severely ill patients. It was considered that this category of patients were unable to respond to the questionnaire in view of their challenging clinical state.

\section{Sampling design}

Study population consisted of patients aged at least 25 years who presented for routine ambulatory outpatient care. Systematic random sampling technique was employed in recruitment of participants for the study. From a sampling frame of 3835 per month, a sampling interval of every 12th patient led to the recruitment of 10 patients per day for 32 days. On a daily basis, the first 12 eligible patients presenting to the clinic were subjected to balloting to select the first participant. Thereafter every 12th patient was recruited until the 10th patient for the day was recruited. A total of 400 participants were approached to participate. From this number, 374 optimally completed questionnaires of eligible participants were subjected to statistical analysis. Predetermined minimum sample size was 320.

\section{Data collection}

Data collection was carried out with the use of a structured, pre-coded questionnaire administered by the principal investigator or his resident doctor assistant. Participants were assured of the confidentiality of the information they provided. Interviews were conducted in the language in which the respondent felt comfortable. The language is either English language or native language in Western Nigeria (Yoruba). Data were collected on participants' demographic and socio-economic characteristics, in addition to self- reported diagnoses (where applicable) and other information provided by respondents on their medical histories. At the end of the clinic day, questionnaires were matched with the patient records, from which were extracted additional information on each respondent's medical diagnoses and routine medications over a one year period. Only definitive diagnoses from participants self report in conjunction with case file extracts were used for the purposes of analysis. Participants with inconclusive information relating medical diagnoses were dropped and replaced with the next eligible patient. Data extraction was carried out by the researcher and a resident doctor in Family Medicine throughout the study period.

\section{Dependent variables}

The primary outcome, multi-morbidity, was determined using information from self reports of diagnoses and validation with participants' medical records. Multi-morbidity was defined as the co-existence of at least two of the 14 pre-selected chronic conditions within the same patient. These 14 conditions were selected following a review of the monthly morbidity returns at the hospital, which identified them as the most prevalent locally. These are: essential hypertension (or co - morbid with diabetes), musculoskeletal conditions, gastrointestinal conditions, type 2 diabetes mellitus (or co - morbid with hypertension), bronchial asthma, other cardiovascular conditions (congestive cardiac failure, stroke and ischaemic heart disease taken together with primary cardiac disease), cataract with primary disease, chronic obstructive pulmonary disease, allergic diseases of skin, nose or eye, sickle 
cell disease, chronic anaemia, chronic liver disease, psychiatric disorders (anxiety, depression, somatisation disorder, sleep disorder) and benign prostatic hypertrophy.

Hypertension and type 2 diabetes mellitus were taken as individual entities if co morbid with each other to forestall selection bias and differential misclassification error. The group 'other cardiovascular conditions' included three possible diagnoses, namely ischaemic heart disease, congestive cardiac failure and stroke taken together with the primary disease. The term 'musculoskeletal conditions' referred to all types of arthritis and chronic back pain (lumbago), and 'gastrointestinal conditions' comprised chronic gastritis, tumours and chronic peptic/gastric ulcers While we used these groupings to conform to the routine hospital records, the specific diseases included in each group were selected based on the existing data at the hospital. For a condition such as anaemia that could be considered either chronic or acute, 3 months shall be defined as the minimum duration for a case to be classified as chronic. All conditions were recorded for analysis according to the documented diagnosis confirmed by the investigator or his assistant except for musculoskeletal conditions, cardiovascular conditions and gastrointestinal conditions, which were composite diagnoses as previously described.

\section{Independent variables}

Information on socio - demographic characteristics including age, gender, marital status, educational level, and income were reported by the participants. These variables are expected to be positively associated with multi-morbidity. In literature, multi-morbidity is shown to be associated with age and females usually have higher multi-morbidity prevalence than males [25]. It is also expected that socioeconomic status is associated with multi-morbidity [35, 36]. Occupation and education have been shown to be positively related to self-reported health $[36,37]$, thus we expect these variables to be negatively associated with multi-morbidity. Low income also has an inverse relationship with prevalence of multi-morbidity [36].

Age from last birthday were measured in single years from 25 years and included as a nominal variable ( 1 - young adult, 2 - middle age and 3 - elderly) to estimate relationships and as continuous variable to predict multi-morbidity form multiple logistic regression. Gender shall be categorized as 1 - female and 0 - male.

\section{Socioeconomic classifications}

There is no consensus on various socioeconomic classifications in Nigeria, because of the unstructured nature of the society. Ijezie and colleagues in Abia State, Nigeria [37] used monthly income and individual educational level as independent determinants of socioeconomic status (SES). Income included all possible sources of income available to the individual. Therefore, for the purpose of this study, respondents were categorized into three classes, according to their reported income. Low income earners were those receiving 18,500 Naira (\#) or less per month - the minimum wage in Nigeria. The middle income class earning \#85,000 or less per month - about the salary level of a newly employed Nigerian graduate. The upper income class earned more than $\$ 85,000$ per month, (one US dollar is equivalent to 150-160 Naira). Educational level was defined as the highest level of individual education completed, and was categorized into four groups: No formal education, primary, secondary and tertiary.

\section{Reports on lifestyle risk factors of multi-morbidity}

To measure obesity, the body mass index (BMI) was calculated from weight (measured in kilograms - Kgs) divided by height squared (metres $-\mathrm{m}^{2}$ ). A BMI greater than $30 \mathrm{~kg} / \mathrm{m}^{2}$ was considered to be obese. A binary variable was thus generated, 1 if obese and 0 non - obese.

Information on smoking was obtained from the participants in the questionnaire using the modified Monica Smoking Questionnaire [38]. Response to the questionnaire by the participants were categorised them into 4 groups - (1.) regular smokers, (2) occasional 
smokers, (3) past smokers and (4) no smokers. A binary variable was generated for logistic regressions analysis; 1 current smokers and 2 non smokers (groups 2, 3 and 4).

Alcohol intake was assessed in the questionnaire using the modified Five-Shot Questionnaire Alcohol Screening Test [39]. A score of 2.5 or greater indicates possible alcohol abuse (1) and less than 2.5 (0).

Exercise was assessed in the questionnaire using the modified Obligatory Exercise Questionnaire [40]. Participants' responses were used to categorise them into two groups (1). Engaging in obligatory exercise and (2) Not engaging in obligatory exercise.

Stress was assessed by ASE questionnaire [41]. Scores equal to or more than 10 showed current stress (1). Scores 9 and below no current stress (0).

Dietary habit was assessed by a score adapted from Food Consumption Score and Healthy Eating Index [42, 43].

Intake of the following 8 food groups were assessed.

- Cereals, tubers, beans, nuts.

- Vegetables and leaves.

- Fruits.

- Dairy products and milk.

- Animal food ; meat and fish

- Oils, fats, butter.

- Sugar and sweet drinks.

- Excess salt intake; adding salt to food while eating.

Frequency of each food intake was assessed over the past seven days. For each item, participants were asked to indicate how many days they consumed the food item in the past seven days. The intake of food each group was scored as $\mathrm{x} / 7$.

Following the Dietary Approach to Stop Hypertension (DASH) guidelines [61], the 8 food groups were divided into healthy group, unhealthy and mixed group viz.

Healthy groups $1-4$ (maximum score 28 , minimum score 0 )

Unhealthy groups 5 - 8 (maximum score 28 , minimum score 0 )

Mixed group if score in $\mathrm{A}$ is equal to score in $\mathrm{B}$.

Each participant in the study was classified based on the class where the participant obtained the highest score.

It is expected that these lifestyle risk factors shall be positively associated with multimorbidity as observed with chronic diseases [21].

Pretesting of questionnaire; The questionnaire was pretested on 30 participants in the general outpatient clinic of Federal Medical Centre, Abeokuta with the aim of refining the questions or clarify ambiguous questions.

\section{Data analysis}

All statistical analyses were done with STATA software version 12 (Stata Corp. Inc. TX, USA). Data from the completed questionnaires was inputted into Microsoft Excel 2010. The resulting datasets were cleaned and then be imported into STATA version 13 for analysis. Socio-demographic characteristics of the participants were described using proportions, percentages, and tables. Inference from relationship between dependent variable and independent variables were drawn from results of chi square analysis and odds ratio with $95 \%$ confidence intervals. The odds ratio and the corresponding 95\% confidence interval showed the strength of association and the degree of precision of the estimate between individual independent variable and the dependent variable (multi-morbidity).

Multiple logistic regression modelling was used to predict the adjusted effect of socio demographic characteristics and lifestyle factors on multi-morbidity. Since the relationship between the lifestyle factors and multi-morbidity is complex, the multiple logistic regressions helped to predict the strength of association between lifestyle factors individually and 
collectively having adjusted for the effect of each lifestyle factor. A p - value of less than 0.05 was taken as statistically significant.

\section{Ethical considerations}

Adequate attention was taken to ensure confidentiality and maintain participation throughout the study period. There was no participant discrimination relating to language, educational level, occupation and ethnic group. Only the researcher had access to the link between nominal information and the unique study identification code. Participants freely sign an informed consent to participate in the study, and the individual's right to withdraw partially or completely was reiterated at data collection. The informed consent document was adequate, contained sufficient information, in simple language and clear. The study obtained ethical approval by Federal Medical Center Abeokuta ethical review committee. Risk of stigmatisation of the participants was mitigated by administering the questionnaire to the participants during normal clinic visit. Acutely or severely ill were excluded from the study as stated in the inclusion/exclusion criteria.

\section{Results}

A total of 374 optimally completed questionnaires were statistically interrogated. The prevalence of chronic diseases among the study population was $56.15 \%$.The three most frequent chronic diseases were hypertension, musculoskeletal problems and diabetes mellitus (Table 1).

Multimorbidity was diagnosed in $26.74 \%$ of the participants. Among the participants with multimorbidity, the most frequent combinations of chronic diseases are as shown in Table 2.

The numbers of males and females participants were 168 (44.92\%) and 206 (55.08\%) respectively. There was no statistically significant difference between males and females in the occurrence of multimorbidity although females were $24 \%$ less likely to have multimorbidity than males (Table 1).

Age group analysis showed that 192 (51.34\%) were in the age group 25 to 45, 148 (39.57\%) in the age group 46 to 65 and 34 (9.09\%) were above 65 years. The higher the age group, the more the likelihood of multimorbidity. Majority (52.41\%) of the participants were in the middle income group. A higher income group was associated with lower likelihood of multimorbidity. Also, majority (64.71\%) of the participants had tertiary education. Increasing educational level was associated with lower likelihood of multimorbidity. About eighty six percent of the participants were currently staying with a partner. Staying with partner had no statistically significant association with multimorbidity but $21 \%$ less likely to have multimorbidity.

In summary therefore, there was statistically significant relationship between occurrence of multimorbidity and older age group, higher level of education, low level of monthly income and low level of education (Table 3).

\section{Lifestyle factors and multimorbidity}

There was increased likelihood of multimorbidity with increasing BMI. Overweight participants had $77 \%$ increased likelihood of multimorbidity while obese participants had $87 \%$ increased likelihood of multimorbidity (Table 3). The data showed that smokers were over fourteen times more likely to develop multimorbidity than non smokers. Also participants who exercised had 57\% less likelihood of developing multimorbidity than participants who did not exercise. There were no statistically significant relationships between alcohol abuse, stress, taking healthy diet and multimorbidity in this study.

After adjusting for confounders, multiple logistic regressions analysis showed that higher age group (OR 3.20, 95\% CI 2.02 - 5.04), BMI > 25 (OR 1.44 95\% CI 1.06 - 1.97), exercise (OR 95\% CI), smoking (OR 0.33, 95\% CI $0.19-0.58$ ) were predictors of multimorbidity occurrence. 
Texila International Journal of Medicine

Volume 5, Issue 1, Jun 2017

\section{Discussion}

This study has revealed the distribution of chronic diseases and multimorbidity in the study population. We also determined the relationship of some socio-demographic variables and lifestyle factors with multimorbidity in a developing country setting.

In this study population, more than fifty percent of the participants had chronic diseases. The three most frequent chronic diseases were hypertension, musculoskeletal problems and diabetes mellitus. A similar study in Ghana in 2013 showed the same pattern [18]. Current evidences are supporting an increasing prevalence of chronic diseases in developing countries $[16,86]$. In most developing populations, the burden of chronic disease has overtaken that of communicable disease partly because of success in reducing the latter, but tragically, also because poor countries are increasingly adopting the unhealthy lifestyles of the developed world.[16]) More research is needed to identify a full range of prevention-focused, costeffective interventions against chronic diseases in the developing world.

A little over a quarter of all participants in this study were diagnosed with multimorbidity. We indentified a study in Ghana [18] with a prevalence of $38.8 \%$ and another one in India [44] with a prevalence rate of $57 \%$ in the rural elderly population. Although our prevalence rate of multimorbidity is less than these two populations, there is an urgent need to develop a holistic approach beyond the management of individual diseases to reverse the trend.

Gender analysis showed that there was no statistically significant difference between males and females in the occurrence of multimorbidity although females were $24 \%$ less likely to have multimorbidity than males. This is in agreement with a study in Australia [45]. Results of some other studies were at variance with this finding [13, 18, 46, 47]. Reasons for this increased risk in females may be due to genetic factors, living and working environments, life events, behavioural risk factors or the general risks associated with low socio-economic status [13]. In this study population, the increased likelihood of multimorbidity in males may be due to the fact that males utilize health services less than females and thus benefits of prevention efforts were less [24-26].

Increasing age was found to be a significant socio-demographic risk factor for multimorbidity. Our results showed that participants above 65 years were about eight and five times more likely to have multimorbidity than those in ages below 45 years and between 46 and 65 respectively. Similar trend have been almost conclusively proven in other studies. [46, 47]. While it is pertinent to give increased consideration to persons with multimorbidity, the elderly should be given particular attention relating to continuous and integrated care [48].

Our data showed that both education and occupation were associated with multimorbidity in the univariate logistic models only, and did not show any association with multimorbidity after adjusting for other factors. Similar conclusions were drawn by a Canadian study [49], which found only a crude association between education and multimorbidity. Socio-economic status (SES) is usually measured by determining level of education, income, occupation or a composite of these indicators [50]. The absence of a clear association could be due to the methods of assessment used, or due to the interplay between the influences of a sedentary lifestyle with higher SES, greater health awareness and improved access to health care - or the reverse scenario for participants with low SES [18]

\section{Lifestyle factors and multimorbidity}

Results of this study suggest an increased likelihood of multimorbidity with increasing BMI, smoking and lack of exercise. Previous studies showed significant association between lifestyle factors, either individually or collectively and individual chronic conditions. [23, 24 $25,36]$. The evidence in this study associating increasing BMI with increasing likelihood of multimorbidity is supported by earlier studies [43-47,62]. Similarly, several studies agreed with our finding of increased likelihood of multimorbidity among regular smokers [21, 31, 32, 52]. However, the results of Nadel and colleagues are at variance with our finding of an association of smoking habit and multimorbidity in men [24]. 
We found lack of exercise a modifiable risk factor associated with increased likelihood of multimorbidity. Our results confirmed several studies linking physical activity with the prevention of cardiovascular disease, diabetes mellitus, cancer (colon and breast), obesity, hypertension, bone and joint disease and premature death. [26, 3].

There exist several documented adverse effects of heavy alcohol consumption [54, 55, 56, 57]. Our results did not show any association between alcohol consumption and multimorbidity. This finding may be an underestimation of the true effect size as the study sample was drawn from primary care clinic. A different finding is likely in a study conducted in specialist set up where patients with complications of heavy alcohol consumption are managed. Further research in this regard is advocated.

Despite current scientific evidence suggesting a protective role for fruits and vegetables in prevention of many chronic diseases [25, 58, 59, 60], we did not find a significant association between nutrition and multimorbidity in the participants. In this environment, encouragement and motivation should be continued for current dietary practices.

Evidence abound on the adverse effect of chronic stress on the immune, cardiovascular, neuroendocrine and central nervous systems with resultant increase on the risk of a range of chronic diseases; mental health problems (insomnia, anxiety, depression), musculoskeletal diseases (osteoarthritis, osteoporosis), cardiovascular diseases, (hypertension, coronary heart disease), weakened immune system (infections), cancers, obesity and HIV/AIDS [61,62,63]. However, in this study, we did not find a significant relationship between chronic stress and multimorbidity. This study design was not appropriate to define this relationship. A case control study is proposed for further assessment of this relationship.

The results of this study supporting the link between lifestyle factors and multimorbidity point to the hypothesis that preventive measures could be considered an intervention in the fight against multimorbidity. An effective approach is an individualized paradigm. A personcentered approach promoting healthy lifestyles would maximize the number of healthy lifestyles in each individual using behavioral change models [64, 65].

\section{Study limitations}

This hospital based cross sectional design should be interpreted with caution to the community. In addition causal inference cannot be made between the explored dependent and independent variables in our study. The administration of the study questionnaires may likely result random misclassification. The crude dichotomous categorization of some lifestyle factors might underestimate the true effect of the various risk factors.

These limitations should be balanced against the strengths of the study, including the systematic random sampling, two group comparison and analytical methods used for the study data.

\section{Conclusions}

This study showed the distribution of chronic diseases and multimorbidity in our setting. The results provide support for the association of unhealthy lifestyle factors and multimorbidity. The increase in the likelihood of multimorbidity with the combined effect of unhealthy lifestyle factors may be used to hypothesise that the promotion of health positive lifestyle factors could be an intervention in the fight against multimorbidity.

\section{Acknowledgements}

I give special thanks to Akintunde Abioye - Kuteyi for providing the guidance right from protocol development, through study conduct to the eventual write up of the article. 
Texila International Journal of Medicine

Volume 5, Issue 1, Jun 2017

\section{Tables}

Table 1. Frequency of the chronic diseases in the study population

\begin{tabular}{|l|l|l|}
\hline Chronic disease & Number & Percentage \\
\hline Hypertension & 112 & $29.95 \%$ \\
Diabetes & 42 & $11.23 \%$ \\
\hline Musculoskeletal & 74 & $19.79 \%$ \\
Copd & 0 & 0 \\
\hline Asthma & 12 & $3.21 \%$ \\
\hline Sickle cell & 2 & $0.54 \%$ \\
\hline BPH & 6 & $1.60 \%$ \\
\hline CVD & 2 & $0.53 \%$ \\
\hline $\begin{array}{l}\text { Chronic Liver } \\
\text { disease }\end{array}$ & 0 & 0 \\
\hline GIT & 9 & $2.41 \%$ \\
\hline Psychiatric diseases & 12 & $3.21 \%$ \\
\hline $\begin{array}{l}\text { Cataract } \\
\text { Allergy }\end{array}$ & 6 & $1.60 \%$ \\
\hline
\end{tabular}

Table 2. Common chronic diseases multi-morbidity distribution

\begin{tabular}{|l|l|}
\hline Chronic Diseases Multi-morbidity & $\begin{array}{l}\text { Number of } \\
\text { participants }\end{array}$ \\
\hline Hypertension and musculoskeletal conditions. & 28 \\
\hline Hypertension and diabetes mellitus. & 26 \\
\hline Diabetes Mellitus and musculoskeletal conditions. & 16 \\
Musculoskeletal conditions and psychiatric disorders. & 10 \\
\hline Three chronic diseases & 9 \\
\hline
\end{tabular}

Table 3. Socio-demographic variables and multimorbidity

\begin{tabular}{|c|c|c|c|c|}
\hline Variable & Multimorbidity & $\begin{array}{l}\text { No } \\
\text { multimorbidity }\end{array}$ & $P$ value & $\begin{array}{l}\text { OR (univariate } \\
\text { analysis) }\end{array}$ \\
\hline $\begin{array}{l}\text { Gender } \\
\text { Male } \\
\text { Female }\end{array}$ & $\begin{array}{l}50 \\
50\end{array}$ & $\begin{array}{l}118 \\
156\end{array}$ & 0.233 & 0.76 \\
\hline $\begin{array}{l}\text { Age group } \\
25-45 \\
46-65 \\
>65\end{array}$ & $\begin{array}{l}24 \\
58 \\
18 \\
\end{array}$ & $\begin{array}{l}168 \\
90 \\
16 \\
\end{array}$ & 0.001 & $\begin{array}{l}1 \\
4.57 \\
8.04 \\
\end{array}$ \\
\hline $\begin{array}{l}\text { Income } \\
\leq 18,500 \\
18,501- \\
85,000 \\
\geq 85,501\end{array}$ & $\begin{array}{l}28 \\
40 \\
32 \\
\end{array}$ & $\begin{array}{l}34 \\
156 \\
\\
84 \\
\end{array}$ & 0.001 & $\begin{array}{l}1 \\
0.31 \\
0.45\end{array}$ \\
\hline $\begin{array}{l}\text { Education } \\
\text { None } \\
\text { Primary } \\
\text { Secondary } \\
\text { Tertiary } \\
\end{array}$ & $\begin{array}{l}8 \\
14 \\
28 \\
50\end{array}$ & $\begin{array}{l}6 \\
16 \\
60 \\
192 \\
\end{array}$ & 0.001 & $\begin{array}{l}1 \\
0.66 \\
0.35 \\
0.20 \\
\end{array}$ \\
\hline $\begin{array}{l}\text { Staying with } \\
\text { partner } \\
\text { No } \\
\text { Yes }\end{array}$ & $\begin{array}{l}16 \\
84\end{array}$ & $\begin{array}{l}36 \\
238\end{array}$ & 0.479 & 0.79 \\
\hline
\end{tabular}


Table 4. Lifestyle factors and multimorbidity

\begin{tabular}{|c|c|c|c|c|}
\hline Variable & Multimorbidity & No multimorbidity & $\mathrm{P}$ value & OR \\
\hline $\begin{array}{l}\text { BMI } \\
<24.99 \\
25-29.99 \\
>30\end{array}$ & $\begin{array}{l}36 \\
26 \\
38\end{array}$ & $\begin{array}{l}140 \\
56 \\
78\end{array}$ & 0.035 & $\begin{array}{l}1 \\
1.77 \\
1.87\end{array}$ \\
\hline $\begin{array}{l}\text { Smoking } \\
\text { No smoker } \\
\text { Smoker }\end{array}$ & $\begin{array}{l}95 \\
5\end{array}$ & $\begin{array}{l}273 \\
1\end{array}$ & 0.002 & 14.37 \\
\hline $\begin{array}{l}\text { Alcohol } \\
\text { abuse } \\
\text { No } \\
\text { Yes }\end{array}$ & $\begin{array}{l}96 \\
4 \\
\end{array}$ & $\begin{array}{l}258 \\
16 \\
\end{array}$ & 0.484 & 0.67 \\
\hline $\begin{array}{l}\text { Exercise } \\
\text { No } \\
\text { Yes }\end{array}$ & $\begin{array}{l}74 \\
26\end{array}$ & $\begin{array}{l}150 \\
124\end{array}$ & 0.001 & 0.43 \\
\hline $\begin{array}{l}\text { Stress } \\
\text { No } \\
\text { Yes }\end{array}$ & $\begin{array}{l}74 \\
26\end{array}$ & $\begin{array}{l}210 \\
64\end{array}$ & 0.60 & 0.87 \\
\hline $\begin{array}{l}\text { Healthy diet } \\
\text { Mixed }\end{array}$ & 20 & 52 & 0.94 & 1 \\
\hline $\begin{array}{l}\text { No } \\
\text { Yes }\end{array}$ & $\begin{array}{l}36 \\
44\end{array}$ & $\begin{array}{l}96 \\
126\end{array}$ & & $\begin{array}{l}0.96 \\
0.90\end{array}$ \\
\hline
\end{tabular}

Table 5. Multiple logistic regressions analysis

\begin{tabular}{|l|c|}
\hline Multimorbidity & $\begin{array}{l}\text { Odds Ratio P value 95\% confidence } \\
\text { interval }\end{array}$ \\
\hline Education & $0.0960 .6250 .578-1.310$ \\
\hline Income & $0.0730 .6000 .525-1.449$ \\
\hline Age Group & $3.1960 .0012 .023-5.050$ \\
\hline BMI group & $1.4430 .0201 .051-1.967$ \\
\hline Smoke & $0.2110 .0900 .720-93.075$ \\
\hline Exercise & $0.3270 .0010 .185-0.575$ \\
\hline
\end{tabular}

\section{References}

[1]. Autenrieth CS, Kirchberger I, Heier M, Zimmermann AK, Peters A, Doring A, Thorand B. (2013). Physical activity is inversely associated with multimorbidity in elderly men: results from the KORA-Age Augsburg study. Prev Med. 57:17-19.

[2]. Agborsangaya CB, Lau D, Lahtinen M, Cooke T, Johnson JA. (2012). Multimorbidity prevalence and patterns across socioeconomic determinants: a cross-sectional survey. BMC Public Health. 12:201.

[3]. Anderson, N.B. (1998). "Levels of Analysis in Health Science: A Framework for Integrating Sociobehavioral and Biomedical Research,” Annals of the New York Academy of Sciences. 8. Vol. 840, pp. 563-576.

[4]. Aarts S, den Akker M, Bosma H, Tan F, Verhey F, Metsemakers J, van Boxtel M. (2012). The effect of multimorbidity on health related functioning: temporary or persistent? Results from a longitudinal cohort study. J Psychosom Res. 73(3):211-217.

[5]. Akesson A, Weismayer C, Newby PK, Wolk A. (2007). Combined effect of low-risk dietary and lifestyle behaviors in primary prevention of myocardial infarction in women. Arch Intern Med., 167:2122-2127.

[6]. Alaba O, and Chola L. (2013). ; The social determinants of multimorbidity in South Africa. International Journal for Equity in Health. 12:63 http://www.equityhealthj.com/content/12/1/63. Viewed August 5, 2014. 
Texila International Journal of Medicine

Volume 5, Issue 1, Jun 2017

[7]. Adedoyin RA, Adesoye A. (2005). Incidence and pattern of cardiovascular disease in a Nigerian Teaching Hospital. Trop Doct. 35104-6

[8]. Booth HP, Prevost AT, Gulliford MC. (2014). Impact of body mass index on prevalence of multimorbidity in primary care: cohort study. Fam Pract. 31(1):38-43.

[9]. Baum, A. (1990). “Stress, Intrusive Imagery, and Chronic Distress," Health Psychology, Vol. 6, pp. 653-675.

[10]. Buddy T, Five - Shot Questionnaire Alcohol Screening Test - About.com Guide. Updated May 01, 2010. Alcohol Concern. "Primary Care Alcohol Information Service - Screening tools for healthcare settings.” Viewed August 15, 2014.

[11]. Britt HC, Harrison CM, Miller GC, Knox SA. (2008). Prevalence and patterns of multimorbidity in Australia. Med J Aust. 189(2):72-77.

[12]. Booth BP, Prevost AT, Gulliford MC. (2014). Impact of body mass index on the prevalence of multimorbidity in primary care: cohort study. Family Practice. Vol. 31 No. 1, 38-43

[13]. Banjare P, Pradhan J Socio-Economic Inequalities in the Prevalence of Multi-Morbidity among the Rural Elderly in Bargarh District of Odisha (India). PLoS ONE 2014 9(6): e97832. doi:10.1371/journal.pone.0097832

[14]. Britt HC, Harrison CM, Miller GC, Knox SA. (2008). Prevalence and patterns of multimorbidity in Australia. Med J Aust. 189:72-77.

[15]. Carguilo T (2007). Understanding the health impact of alcohol dependence. Am J Health Syst Pharm 64 (5 suppl 3) : s5-11]

[16]. Chiuve SE, McCullough ML, Sacks FM, Rimm EB. (2006): Healthy lifestyle factors in the primary prevention of coronary heart disease among men: benefits among users and nonusers of lipidlowering and antihypertensive medications. Circulation. 114:160-167.

[17]. Cohen S, Janicki-Deverts D, Miller GE (2007). "Psychological stress and disease”. JAMA 298

(14): 1685-1687. doi:10.1001/jama.298.14.1685. PMID 17925521.

[18]. Chukwuonye CI, Chuku A, Okpechi IG, Ugochukwu Uchenna Onyeonoro. (2013). UU, Madukwe OO, Okafor GOC, Ogah OS, Socioeconomic status and obesity in Abia State, South East Nigeria. Diabetes, Metabolic Syndrome and Obesity: Targets and Therapy. 6 371-378

[19]. Darren E.R. Warburton, Crystal Whitney HYPERLINK "http://www.ncbi.nlm.nih.gov/pubmed/?term=Nicol\%20CW\%5Bauth\%5D"

[20]. Nicol, and Shannon S.D. HYPERLINK “http://www.ncbi.nlm.nih.gov/pubmed/?term=Bredin\%20SS\%5Bauth\%5D” Bredin. (2006). Health benefits of physical activity: the evidence CMAJ. 174(6): 801-809. doi: 10.1503/cmaj.051351 PMCID: PMC1402378

[21]. de S Santos Machado V, Valadares AL, Costa-Paiva LH, Osis MJ, Sousa MH, Pinto-Neto AM. (2013). Aging, obesity, and multimorbidity in women 50 years or older: a population-based study. Menopause 20(8):818-824.

[22]. HYPERLINK "http://www.nhlbi.nih.gov/health/public/heart/hbp/dash/new_dash.pdf” Your HYPERLINK

"http://www.nhlbi.nih.gov/health/public/heart/hbp/dash/new_dash.pdf" Guide To Lowering Your Blood Pressure With DASH (PDF). US Department of Health and Human Services. April 2006.

[23]. De Souza Santos Machado V, Valadares AL, Da Costa-Paiva LS, Moraes SS, Pinto-Neto AM. (2012). Multimorbidity and associated factors in Brazilian women aged 40 to 65 years: a populationbased study. Menopause. 19(5):569-575.

[24]. Ford ES, Bergmann MM, Kroger J, Schienkiewitz A, Weikert C, Boeing H. (2009). Healthy living is the best revenge: findings from the European Prospective Investigation into Cancer and Nutrition-Potsdam study. Arch Intern Med. 169:1355-1362.

[25]. Forman JP, Stampfer MJ, Curhan GC. (2009). Diet and lifestyle risk factors associated with incident hypertension in women. JAMA. 302:401-411.

[26]. Fortin M, Bravo G, Hudon C, Lapointe L, Almirall J, Dubois MF, Vanasse A. (2006). Relationship between multimorbidity and health-related quality of life of patients in primary care. Qual Life Res. 15:83-91. 
[27]. Fortin M, Dubois MF, Hudon C, Soubhi H, Almirall J. (2007). Multimorbidity and quality of life: a closer look. Health Qual Life Outcomes. 5:52.

[28]. Fortin M, Haggerty J, Almirall J, Bouhali T, Sasseville M and Lemieux M. (2014). Lifestyle Factors and multimorbidity: a cross sectional study. BMC Public Health 14:686 http://www.biomedcentral.com/1471-2458/14/686. Viewed August 6, 2014.

[29]. Glynn LG, Valderas JM, Healy P, Burke E, Newell J, Gillespie P, Murphy AW. (2011). The prevalence of multimorbidity in primary care and its effect on health care utilization and cost. Fam Pract. 28(5):516-523.

[30]. Guenther PM, Krebs-Smith SM, Reedy J, Reeve BB, Basiotis PP. (2007). Development and evaluation of healthy eating index. USDA Center for Nutrition Policy and Promotion and National Cancer Institute.

[31]. Househam KC. (2010).Africa's Burden of disease: the university of cape town Sub-saharan africa centre for chronic disease. South Afr Med J. 100(2):94-95.

[32]. Heiner Boeing, Angela Bechthold, Achim Bub, Sabine Ellinger, Dirk Haller, Anja Kroke, Eva Leschik-Bonnet, Manfred J. Muller, Helmut Oberritter, Matthias Schulze, Peter Stehle, Bernhard Watzl. (2012).Critical review: vegetables and fruit in the prevention of chronic Diseases. Eur J Nutr 51:637-663 DOI 10.1007/s00394-012-0380-y

[33]. Hall JN, Moore S, Harper SB, Lynch JW (2009) Global variability in fruit and vegetable consumption. Am J Prev Med 36:402-409

[34]. Interagency Workshop Report WFP - FAO. Measures of Food Consumption - Harmonizing Methodologies Rome, 9 - 10 April 2008.

[35]. Kent JA, Patel V, and Varela NA. (2012). Gender disparities in health care. Mount Sinai Journal of Medicine. 79 (5): 555-559. http://dx.doi.org/10.1002/msj.21336

[36]. Khanam MA, Streatfield PK, Kabir ZN, Qiu C, Cornelius C, Wahlin A. (2011). Prevalence and patterns of multimorbidity among elderly people in rural Bangladesh: a cross-sectional study. J Heal Popul Nutr. 29(4):406-414.

[37]. McCormick WC, Boling PA. (2005). Multimorbidity and a Comprehensive Medicare CareCoordination Benefit. J Am Geriatr Soc. 53(12):2227-2228.

[38]. Maiyaki MB, Garbati MH. (2014).The burden of non - communicable disease in Nigeria in the context of globalization. Ann. Afr. Med. 131-10

[39]. Myint PK, Luben RN, Wareham NJ, Bingham SA, Khaw KT. (2009). Combined effect of health behaviours and risk of first ever stroke in 20,040 men and women over 11 years' follow-up in Norfolk cohort of European Prospective Investigation of Cancer (EPIC Norfolk): prospective population study. BMJ 338:b349.

[40]. Muller D, Koch RD, von Specht H, Volker W, Munch EM. (1985).Neurophysiologic findings in chronic alcohol abuse. Psychiatr Neurol Med Psychol 1985. 37(3):129-32.

[41]. Marengoni A, Winblad B, Karp A, Fratiglioni L. (2008). Prevalence of chronic diseases and multimorbidity among the elderly population in Sweden. Am J Public Health. 98:1198-1200.

[42]. Marengoni A, Rizzuto D, Wang HX, Winblad B, Fratiglioni L (2009). Patterns of chronic multimorbidity in the elderly population. J Am Geriatr Soc. 57:225-230.

[43]. Nimako BA, Baiden F, Sackey SO, Binka F 1. (2013). Multimorbidity of chronic diseases among adult patients presenting to an inner-city clinic in Ghana. Globalization and Health. 9:61

[44]. Nugent R, Ann. N.Y. Acad. Sci. 1136: 70-79 (2008). C _ 2008 New York Academy of Sciences. doi: 10.1196/annals.1425.027

[45]. http://www.globalizationandhealth.com/content/9/1/61. Viewed August 52014.

[46]. Policy and action for cancer prevention. Food, nutrition, and physical activity: a global perspective.

[http://www.dietandcancerreport.org/cancer_resource_center/downloads/Policy_Report.pdf]

[47]. Reis JP, Loria CM, Sorlie PD, Park Y, Hollenbeck A, Schatzkin A. (2011). Lifestyle factors and risk for new-onset diabetes: a population-based cohort study. Ann Intern Med. 155:292-299.

[48]. Ronksley PE, Brien SE, Turner BJ, Mukamal KJ, Ghali WA. (2011). Association of alcohol consumption with selected cardiovascular disease outcomes: a systematic review and meta-analysis. BMJ. 342:d671. Doi10.1136/bmj.d671 
Texila International Journal of Medicine

Volume 5, Issue 1, Jun 2017

[49]. Steyn K, Damasceno A. (2006). Lifestyle and Related Risk Factors for Chronic Diseases .In 2nd edition Edited by Jamison DT, Feachem RG, Makgoba MW, Bos ER, Baingana FK, Hofman KJ, Monica Smoking Questionnaire. MONICA Manual, Part III, Section 1. www.ktl.fi/publications/monica/manual/part3/smquest3.htm Viewed August 15, 2014

[50]. Self-Scoring Stress Questionnaire. www.carolespiersgroup.co.uk/stress-questionnaire.html. Accessed August 142014.

[51]. Schafer I, Hansen H, Schon G, Hofels S, Altiner A, Dahlhaus A, Gensichen J,Riedel-Heller S, Weyerer S, Blank WA. (2012). The influence of age, gender and socio-economic status on multi morbidity patterns in primary care. First results from the multicare cohort study. BMC Health Serv Res., 12(89): doi:10.1186/1472-6963-12-89.

[52]. Starfield B, Lemke KW, Bernhardt T, Foldes SS, Forrest CB, Weiner JP. (2003). Comorbidity: implications for the importance of primary care in 'Case' management. Ann Fam Med. 1(1):8-14.

[53]. Sasazuki S, Inoue M, Iwasaki M, Sawada N, Shimazu T, Yamaji T, Tsugane S.(2012). Combined impact of five lifestyle factors and subsequent risk of cancer: the Japan Public Health Center Study. Prev Med. 54:112-116.

[54]. Thompson, J. K. \& Pasman, L. The Obligatory Exercise Questionnaire. http://jkthompson.myweb.usf.edu/oeqweb.htm. Accessed August 18, 2014

[55]. Tolsrup J, Jensen MK, Tjonneland A, Overvad K, Mukamal KJ, Gronbaek M. (2006).Prospective study of alcohol drinking patterns and coronary artery disease in women and men. BMJ; 332(7552):1244 -8.E pub 2006 May3.

[56]. Taylor B, Rehm J, Gmel G, (2005).Moderate alcohol consumption and the gastrointestinal tract. Dig. Dis. 23(3-4); 170-6].

[57]. Tucker-Seeley R, Li Y, Sorensen G, Subramanian S: Lifecourse socioeconomic circumstances and multimorbidity among older adults. BMC Publ Health 2011, 11:313.

[58]. Uijen AA, van de Lisdonk EH. (2008). Multimorbidity in primary care: prevalence and trend over the last 20 years. Eur J Gen Pract. 14 (Suppl 1):28-32.

[59]. U.S. Department of Health and Human Services: Physical Activity and Health: A Report of the Surgeon General. Atlanta, GA: Department of Health and Human Services, Centers for Disease Control and Prevention, National Center for Chronic Disease Prevention and Health Promotion; 1996.

[60]. Valderas JM, Starfield B, Sibbald B, Salisbury C, Roland M. (2009). Defining comorbidity: implications for understanding health and health services. Ann Fam. 7:357-363.

[61]. World Health Report 2002: reducing risks, promoting healthy life. [http://www.who.int/whr/2002/en/Overview_E.pdf]. Viewed August 7, 2014.

[62]. WHO (2008) WHO report on the Global Tobacco Epidemic. Retrieved 19 - 09 - 2014.

[63]. WHO Report on the Global Tobacco Epidemic? World Health Organization. (2008). Retrieved 19 $-9-2014$.

[64]. Winkleby MA, Jatulis DE, Frank E, Fortmann SP: (1992). Socioeconomic status and health: how education, income, and occupation contribute to risk factors for cardiovascular disease. Am J Public Health. 82:816-820.

[65]. Zeba AN, Delisle HF, Genevieve R, Boubacar S, Banza B. (2012). The double burden of malnutrition and cardiometabolic risk widens the gender and socioeconomic health gap: a study among adults in Burkina Faso (West Africa). Public Health Nutr. 15(12):2210-2219. 


\title{
Comparative Analysis of the in-vitro Susceptibility of Salmonella Typhi to Chloramphenicol and Leaf Extracts of Moringa Oleifera
}

\author{
Article by Oche Joseph Otorkpa \\ Usmanu Danfodiyo University, Sokoto State \\ E-mail: ochejoseph@yahoo.com
}

\begin{abstract}
The objective of this study was to compare the in-vitro susceptibility of clinical isolates of Salmonella typhi to Chloramphenicol and leaf extracts of Moringa oleifera. The in-vitro effects of both substances were evaluated using ethanol, ether, hot and cold water extracts of the plants leaf. The hot and cold water extracts showed no activity against the organism while the organism was sensitive to the ethanol and ether extracts at concentrations of 40,60,80, 100 , and $120 \mathrm{mg} / \mathrm{ml}$ with zones of inhibition $(\mathrm{mm})$ of 4.0, 4.0, 7.0, 9.0, 8.0and 4.0, 6.0, 7.0, 8.0, 8.0 respectively. The organism was also sensitive to two brands of chloramphenicol $A$ and $B$ with zones of inhibition 15.0, 13.0, 14.0, 23.0, and 25.0. 20.0, 18.0, 16.0, 21.0, and 20.0. Respectively at various concentrations. The findings from this study confirms that chloramphenicol has higher in-vitro activity against Salmonella typhias compared to the leaf extract of Moringa oleifera regardless of the method employed in the extraction process
\end{abstract}

Keywords: Salmonella typhi, Susceptibility, Leaf extracts, Medicinal plants, chloramphenicol, Moringa oleifera

\section{Introduction}

Salmonella typhi is a gram negative rod shaped motile non spore forming bacterium belonging to the f family Enterobacteriaceae, this facultative anaerobe is the causative agent of typhoid fever. morphologically it has 2 membranes (outer and an inner), periplasm, and a Lipopolysaccharide chain that consists of $\alpha$-d-galactosyl-( $\rightarrow$ 2)- $\alpha$-d-mannosyl-( $1 \rightarrow 4)-1-$ rhamnosyl-(1 $\rightarrow$ 3)-repeating units, and has short branches of single 3, 6-dideoxyhexose residues]

Humans become infected with Salmonella typhias a result of the ingestion of food or untreated water containing the organism. Once ingested they are taken up by the mononuclear phagocytes whose job it is to engulf and destroy the invading bacteria. However, in some cases the bacteria evade the phagocytes and multiply within the cells and spill into the blood stream where they produce symptoms of the disease. S, typhi is implicated in the death of over half a million people worldwide each year largely due to poor environmental and sanitary conditions especially in developing countries.

The organism is susceptible to a wide range of antibiotics and to date over 107 different strains of the organism have been isolated with different level of virulence, many of these strains have been reported to have complex metabolic features and multi-drug resistance genes that complicates treatment of typhoid fever especially in typhoid fever endemic areas.

Although native to India, Moringa oleifera is a widely distributed plant in Nigeria, it is extensively cultivated in different parts of the country, mainly in family gardens of northern Nigeria. The plant is an Angiosperms belonging to the Order Brassicales and Family Moringaceae. The plant can grow to a height of:10-12 meters, the leaves build up a feathery foliage of tripinnate leaves. The flowers are fragrant and bisexual, surrounded by five unequal, thinly veined, yellowish-white petals. The flowers are about 1.0-1.5 centimeters long and two centimeters broad. They grow on slender, hairy stalks in spreading or drooping later flower clusters which have a length of 10-25 centimeters.

In Africa, especially Sokoto Northwestern Nigeria the leaves and stem of M. oleifera is considered a delicacy and sold as snacks and a remedy for various ailments and infections. In 
other regions the leaves and other parts of the plant are extensively used for a wide variety of purposes due to its rich macro- and micronutrients content. Studies have reported that Moringa oleifera is a good source of vitamin C, Vitamin B, vitamin K and Beta carotene.

\section{Objective of the study}

The increasing level of multi drug resistance pattern and the tendency of salmonella typhi to alter its genotypic and phenotypic features in response to changes in the environment has made it increasing difficult to effectively execute measures that will eradicate the organism from the food chain, this necessitated a research to assess the in-vitro effect of different extracts of Moringa oleifera a widely used medicinal plant and food on the organism.

\section{Materials and method}

The samples were collected as described by Deeni and Aishatu (1994), Mohammed (1996) and Cheesbrough (2000).

\section{Sample collection}

Plant material were collected from local farms in Dundaye village near the permanent site of the Usmanu Danfodiyo University Sokoto, Nigeria. The plant was identified in the Botany unit of the Usmanu Danfodiyo University Sokoto .The leaves were plucked and sundried for two days and later grounded into powder using pestle and mortar. The powder was sieved with an eighty micron sized aperture. The chloramphenicol capsules were obtained from Freedom Pharmacy and French Afrique Pharmacy Sokoto

\section{Test organism}

The test organism (clinical isolates) were obtained from Microbiology laboratory of Usman Danfodiyo University Teaching Hospital, Sokoto.

\section{Processing of plant leaves}

\section{Extraction procedure}

\section{Cold water extract}

Two gram of the powder was weighed using a weighing balance and put into a beaker constraining one hundred milliliters $(100 \mathrm{ml})$ of distilled water left overnight. Similarly procedure was repeated for $3 \mathrm{~g}, 5 \mathrm{~g}, 10 \mathrm{~g}$, and $15 \mathrm{~g}$ of the powder the suspension was then filtered with funnel and cotton wool to obtain the extract. The extract was allowed to stand until the volume reduced to $10 \mathrm{ml}$.

\section{Hot water extract}

Two grams of the powder was weighed using a weighing balance and put into a beaker containing one hundred milliliter $(100 \mathrm{ml})$ of distilled water and boiled on a hot plate. The boiled suspension was then left overnight. The same procedure was carried out using $3 \mathrm{~g}, 5 \mathrm{~g}$, $10 \mathrm{~g}$, and $15 \mathrm{~g}$ of the powder, the suspension was then filtered using cotton wool and funnel. The extract was then concentrated to $10 \mathrm{ml}$ by boiling.

\section{Ethanol Extract}

Ten (10) gram of powder was weighed using a weighing balance. The powder was then dispense into thimble which was place in the soxhlet extractor containing two hundred milliliters (200ml) of the solvent (Ethanol).

The soxhlet extractor was then operated until colour change became visible indicating that the extraction process has commenced this continued until no further change in the colour of the solvent was visible and thus marked the end of the extraction process.

The ethanol was separated from the extract by heating and condensation of the ethanol into the extractor and collection of the extract in a $10 \mathrm{ml}$ beakers. The same procedure was repeated for $15 \mathrm{~g}, 20 \mathrm{~g}, 25 \mathrm{~g}$ and $30 \mathrm{~g}$ 


\section{Ether extract}

Ten (10) grams of the powder was weighed using a weighing balance. The powder was then dispensed into the thimble, which was then placed in the soxhlet extractor containing two hundred milliliters $(200 \mathrm{ml})$ of the solvent (ether). The soxhlet extractor was then operated until colour change became visible indicating the commencement of the extraction process.

This continued until there was no further change in colour of the solvent, which marked the end of the extraction process.

The ether was then separated from the extract by heating and condensation of ether into extractor and the collection of the extract in a $(10 \mathrm{ml})$ beaker.

The same procedure was repeated for $15 \mathrm{~g}, 20 \mathrm{~g}, 25 \mathrm{~g}$ and $30 \mathrm{~g}$

\section{Preparation of media}

The media were prepared according to manufacturer's specifications.

\section{Preparation of Disc}

Disc of about $6.0 \mathrm{~mm}$ in diameter were punched from what man filter paper No. 1 and sterilized in a hot air oven at 160 oc for 1 hour.

The antibiotics solutions were made using sterile distilled water. The disc were then put into the varying concentrations of the antibiotic solution and extract and allowed to soak all the liquid after which they were air dried.

\section{Sensitivity test}

Discs diffusion techniques was employed as described by chees borough (2000), Edward (1979), Lacey (1984), Deeni and Aishatu (1994).

\section{Results}

The cold water, hot water and ethanol of showed no activity in-vitro on clinical isolates of Salmonella typhi

Table 1. Shows the susceptibility of Salmonella typhi in zones of inhibition (mm) obtained against different concentrations of ethanol extract of Moringa oleifera

\begin{tabular}{|l|l|l|}
\hline $\begin{array}{l}\text { Concentration } \\
(\mathrm{mg} / \mathrm{ml})\end{array}$ & $\begin{array}{l}\text { Zones of } \\
\text { inhibition }(\mathrm{mm})\end{array}$ & Control \\
\hline 40 & 4 & $\begin{array}{l}\text { Chloramphenicol } \\
250 \mathrm{mg} / 25 \mathrm{ml}\end{array}$ \\
\hline 60 & 4 & $\begin{array}{l}\text { Chloramphenicol } \\
250 \mathrm{mg} / 25 \mathrm{ml}\end{array}$ \\
\hline 80 & 7.0 & $\begin{array}{l}\text { Chloramphenicol } \\
250 \mathrm{mg} / 25 \mathrm{ml}\end{array}$ \\
\hline 100 & 9.0 & $\begin{array}{l}\text { Chloramphenicol } \\
250 \mathrm{mg} / 25 \mathrm{ml}\end{array}$ \\
\hline 120 & 8.0 & $\begin{array}{l}\text { Chloramphenicol } \\
250 \mathrm{mg} / 25 \mathrm{ml}\end{array}$ \\
\hline
\end{tabular}

\section{Salmonella typhi}

Table 2. shows the susceptibility of Salmonella typhi in zones of inhibition (mm) obtained against different concentrations of ether extract of Moringa oleifera

\begin{tabular}{|l|l|l|}
\hline $\begin{array}{l}\text { Concentration }(\mathrm{mg} \\
/ \mathrm{ml})\end{array}$ & $\begin{array}{l}\text { Zones of inhibition } \\
(\mathrm{mm})\end{array}$ & Control \\
\hline 40 & 4.0 & Chloramphenicol \\
\hline
\end{tabular}


Texila International Journal of Medicine

Volume 5, Issue 1, Jun 2017

\begin{tabular}{|l|l|l|}
\hline & & $250 \mathrm{mg} / 25 \mathrm{ml}$ \\
\hline 60 & 6.0 & $\begin{array}{l}\text { Chloramphenicol } \\
250 \mathrm{mg} / 25 \mathrm{ml}\end{array}$ \\
\hline 80 & 7.0 & $\begin{array}{l}\text { Chloramphenicol } \\
250 \mathrm{mg} / 25 \mathrm{ml}\end{array}$ \\
\hline 100 & 8.0 & $\begin{array}{l}\text { Chloramphenicol } \\
250 \mathrm{mg} / 25 \mathrm{ml}\end{array}$ \\
\hline 120 & 8.0 & $\begin{array}{l}\text { Chloramphenicol } \\
250 \mathrm{mg} / 25 \mathrm{ml}\end{array}$ \\
\hline
\end{tabular}

The clinical isolates were highly susceptible to the antibiotic (chloramphenicol).

Table 3. Shows the susceptibility of Salmonella typhi in zones of inhibition (mm) obtained against different concentration of brand A of chloramphenicol.

\begin{tabular}{|l|l|}
\hline $\begin{array}{l}\text { Concentration } \\
(\mathrm{mg} / \mathrm{ml})\end{array}$ & Zones of inhibition (mm) \\
\hline $250 \mathrm{mg} / 10 \mathrm{ml}$ & 15.0 \\
\hline $250 \mathrm{mg} / 20 \mathrm{ml}$ & 13.0 \\
\hline $250 \mathrm{mg} / 30 \mathrm{ml}$ & 14.0 \\
\hline $250 \mathrm{mg} / 40 \mathrm{ml}$ & 23.0 \\
\hline $250 \mathrm{mg} / 50 \mathrm{ml}$ & 25.0 \\
\hline
\end{tabular}

The clinical isolates were also susceptible to Brand B of the antibiotic

Table 4. Shows the susceptibility of Salmonella typhi (zones of inhibition) (mm) obtained against different concentration of brand B of chloramphenicol

\begin{tabular}{|l|c|}
\hline $\begin{array}{l}\text { Concentration } \\
\text { (mg/ml) }\end{array}$ & Zones of inhibition (mm) \\
\hline $250 \mathrm{mg} / 10 \mathrm{ml}$ & 20.0 \\
\hline $250 \mathrm{mg} / 20 \mathrm{ml}$ & 18.0 \\
\hline $250 \mathrm{mg} / 30 \mathrm{ml}$ & 16.0 \\
\hline $250 \mathrm{mg} / 40 \mathrm{ml}$ & 21.0 \\
\hline $250 \mathrm{mg} / 50 \mathrm{ml}$ & 20.0 \\
\hline
\end{tabular}

\section{Discussion}

The results obtained from the study showed that chloramphenicol is still more effective in the management of infections as a result of Salmonella typhi than all the leave extracts of Moringa oleifera analyzed, as evidenced with the higher zones of inhibition $>20$ recorded for various concentration of the drug against those recorded for different extracts of the plant. This findings align with the set standards according to the National Committee for Clinical Laboratory Standards, NCCLS (1997).

Despite the wide spread report of increasing report of multi drug resistance in the management of infections due to salmonella typhi, it is evident from this study that chloramphenicol remains an important agent in the pharmacotherapy of typhoid fever, this also tarries with the recommendations of (Chandel 2000) which reported that the suggestions that quinolones i.e. ciprofloxacin as a remedy to the increasing incidence of resistance recorded in the management of typhoid fever should be reconsidered, as a result of the increasing susceptibility of the organism to chloramphenicol. They submitted that the development of resistance by salmonella typhi to ciprofloxacin is partly related to its exposures to concentrations near their minimum inhibitory concentration (MIC). With increases in MICs, clinicians may be tempted to administer higher doses of ciprofloxacin to achieve serum levels required for effective therapy; however, higher doses could have unwanted clinical and public health consequences. Rather, this in-creased resistance may warrant a restructuring of the chemotherapeutic regimen for enteric diseases, as well as 
restricting use of ciprofloxacin to atypical cases in which lack of clinical response to other therapeutic drugs is noted.

Although water extracts and leaves of Moringa oleifera have been documented to be rich in macro and micro nutrients including manganese, potassium and other essential compounds , water extracts of the plant appear to have no activity intro against clinical isolates of salmonella typhi, this is consistent with the findings of Siddhuraju and Becker (2003) which analyzed the Antioxidant properties of Moringa oleifera and reported that although all leaf extracts were capable of scavenging peroxyl and superoxyl radicals. Similar scavenging activities for different solvent extracts of each collection were found for the stable 1, 1diphenyl 2-picrylhydrazyl ( $\mathrm{DPPH}^{\circ}$ ) radical. Among the three different moringa samples, both methanol and ethanol extracts of Indian origins showed the highest antioxidant activities, 65.1 and $66.8 \%$, respectively, in the $\beta$-carotene-linoleic acid system.

\section{Conclusion}

It should be noted that although ethanol and ether extracts of Moringa oleifera showed some activity $(<10 \mathrm{~mm})$ in vitro against clinical isolates of Salmonella typhi it is comparatively lower than the zone of inhibitions recorded for the different concentration of chloramphenicol $(>19 \mathrm{~mm})$ it is concluded that the antibiotic chloramphenicol is comparatively superior to extracts of Moringa oleifera in the management of infections due to Salmonella typhias indicated.

\section{References}

[1]. Cheesbrough, M., (2000). District laboratory practice in tropical countries. Cambridge University press.pp182-186

[2]. Deeni. Y.Y. and Aishatu M.T (1994) Antimicrobial Susceptibility of Clinical Isolates of Enteric Bacteria in Kano, Nigeria. Orient Journal of Medicine. (1\&2);pp1-4

[3]. Edward, M.J. (1979): Bacterial Susceptibility Testing and Assays in Clinical Diagnosis and management pp. 103-106

[4]. Chandel, D.S., Chaudhry, R., Dhawan, B., Pandey, A. and Dey, A.B., 2000. Drug-resistant Salmonella enterica serotype paratyphiA in India. Emerging infectious diseases, 6(4), p.420.

[5]. Hammer, K.1., Carson, C.F. and Riley, T.V., 2003. Antifungal activity of the components of Melaleuca alternifolia (tea tree) oil. Journal of Applied Microbiology, 95(4), pp.853-860.

[6]. Kita, Hiroshi, and Nikaido Hiroshi. "Structure of Cell Wall Lipopolysaccharide from Salmonella typhimurium IV. Anomeric Configuration of l-Rhamnose Residues and Its Taxonomic Implications". Journal of Bacteriology. 1973. Volume 113. p. 672-679

[7]. Mohammed (1996) Comparative Study of Cassia occidentalis and chloramphenicol .pp 2-21.

[8]. National Committee for Clinical Laboratory Standards. (1997). Methods for Dilution Antimicrobial Susceptibility Tests for Bacteria that Grow Aerobically. Approved Standard M7-A4. NCCLS, Wayne, PA

[9]. Mishra, G., Singh, P., Verma, R., Kumar, S., Srivastav, S., Jha, K. K., \& Khosa, R. L. (2011). Traditional uses, phytochemistry and pharmacological properties of Moringa oleifera plant: An overview. Der Pharmacia Lettre, 3(2), 141-164.

[10]. Pal, S. K., Mukherjee, P. K., Saha, K., Pal, M., \& Saha, B. P. (1995). Antimicrobial action of the leaf extract of Moringa oleifera Lam. Ancient Science of Life, 14(3), 197.

[11]. Prescott LM, Harley JP, Kleen DA (2002). Microbiology, $5^{\text {th }}$ Edition, McGrawHill, NewYork. pp. 774-778 https://en.wikipedia.org/wiki/Moringa_oleifera

[12]. Pal, S.K., Mukherjee, P.K. and Saha, B.P., 1995. Studies on the antiulcer activity of Moringa oleifera leaf extract on gastric ulcer models in rats. Phytotherapy Research, 9(6), pp.463-465.

[13]. Rupali, P., Abraham, O.C., Jesudason, M.V., John, T.J., Zachariah, A., Sivaram, S. and Mathai, D., 2004. Treatment failure in typhoid fever with ciprofloxacin susceptible Salmonella enterica serotype Typhi. Diagnostic microbiology and infectious disease, 49(1), pp.1-3.

[14]. Wain, J., Hoa, N.T., Chinh, N.T., Vinh, H., Everett, M.J., Diep, T.S., Day, N.P., Solomon, T., White, N.J., Piddock, L.J. and Parry, C.M., 1997. Quinolone-resistant Salmonella typhi in Viet Nam: 
Texila International Journal of Medicine

Volume 5, Issue 1, Jun 2017

molecular basis of resistance and clinical response to treatment. Clinical infectious diseases, 25(6), pp.1404-1410. 


\title{
Acute Urinary Retention in a Young Man Secondary to Severe Dysentery: A Case Report
}

\author{
Article by Mohammad Nasir Alvi \\ MD Family Medicine, Texila American University, Pakistan \\ E-mail: nasiralvi74@hotmail.com
}

\begin{abstract}
Urinary bladder has complex Autonomic innervation regulated by a hierarchy of mechanisms of the central nervous system. Any dysfunction in these regulatory mechanisms can lead to acute urinary retention. A 25 years old man presented with acute urinary retention following severe dysentery. His urinary bladder was decompressed and his normal voiding mechanism was restored thereafter. It is postulated that excessive straining to pass stool during dysentery / diarrhea can stimulate the recto-vesicourethral reflex and lead to acute urinary retention.
\end{abstract}

Keywords: Acute urinary retention, Recto-vesicourethral reflex, Dysentery

\section{Introduction}

Complaint of acute retention urine in healthy young men is a rare presentation. Acute urinary retention can be defined as an emergency situation characterized by a sudden inability to void urine and is associated with lower abdominal discomfort and distention [1].

The reasons of acute urinary retention in young men are broadly categorized into neurogenic, obstructive or pharmacologic [2]. The neurogenic causes of acute urinary retention are less common and are injury to spinal cord, multiple sclerosis and prolapsed disc [2]. The obstructive causes of acute urinary retention could also be associated with stricture, severe inflammation of prostate or calculi within the urethra [2]. Narcotics and liquor abuse are thought to be pharmacologic causes of acute urinary retention.

Urgent management of acute urinary retention requires insertion of a urinary catheter to empty the bladder and relieve patient's distress. Nonetheless, more urological investigations ought to be done to see the underlying pathology of such dysfunctional discharge [2].

The manifestation of AUR as results of intestinal abnormalities are explained partially by the common embryology of the lower urinary and anorectal systems. Additional significantly, the recto-vesicourethral reflex is that the main physiologic reflexive mechanism that harmonizes the stool passing and micturition functions within the traditional state. Specific pathophysiological issues like prolonged rectal distention can disrupt the recto-vesicourethral reflex and ultimately cause the event of acute urinary retention.

\section{Case presentation}

A twenty five years old man reported to the emergency department with 08-hours history of acute pain in lower abdominal and distension along with the inability to void urine. The patient had loose stools containing blood and mucous since morning. The dysentery was thus severe that on one occasion he had to remain in the bathroom for about 02 hours making an attempt to force stool out. After that he was unable to void urine. He made several attempts to void urine however no success. Then he developed swelling and pain at suprapubic region and he was taken to emergency department.

There was no history of injury, any urological, neurological or STD. He had no history of substance or liquor abuse. There were no previous lower urinary tract symptoms.

On examination, the patient was in extreme suprapubic discomfort. A painful suprapubic mass was palpable up to the umbilicus. His genital, penile, and digital rectal examination revealed normal. His cardiorespiratory and neurological examinations were also normal. A 
Texila International Journal of Medicine

Volume 5, Issue 1, Jun 2017

provisional diagnosis of acute urinary retention was made and his bladder was emptied by passing 18 FG self retaining Foley catheter that yielded 3500 cc of clear urine.

The results of laboratory blood tests including complete blood picture, C-reactive protein, ESR and blood sugar random were all within the normal limits. The biochemical tests revealed marked rise of s.creatinine level $680 \mu \mathrm{mol} / \mathrm{l}$ (range is sixty to one hundred $\mu \mathrm{mol} / \mathrm{l}$ ) on admission. His urine R/E was normal without pyuria or haematuria. Bilateral moderate hydroureteronephrosis to the level of the urinary bladder was present on renal ultrasonography. His s.creatinine levels dropped to $103 \mu \mathrm{mol} / \mathrm{l}$ eight hours after urinary catheterization.

The patient was then admitted and afterward underwent complete urological and radiological investigations. Post-void residual, uroflowmetry and cystoscopy examinations were performed throughout consecutive few days after hospitalization and the findings were normal. Findings of Urodynamic studies were normal. MRI, (Multiple Sclerosis protocol) of his brain and spinal cord were both normal. Serum creatinine level returned to normal on the second post-admission day. 02 days later, a repeat kidney ultrasonographic examination showed normal sized kidneys and no proof of urinary obstruction.

\section{Discussion}

This is a rare case of acute urinary retention in a young man and it is inferred that this was associated with severe dysentery. There's no similar case within the literature. After full urological and neurological assessments, conclusion was that ano-rectal dilation caused by dysentery was the reason behind his acute urinary retention. Normal urination was restored on second day of presentation in this patient.

Sudden retention of urine followed by dysentery / diarrhea has not been reported. It is explained by the very fact that severe dysentery resulting in rectal distension appears to induce diminished reflex referred to as "recto-vesicourethral reflex." This reflex is seemingly evoked during stool passing to abort simultaneous micturition.

Nerve supply of the bladder is complicated and controlled by a hierarchy of CNS mechanisms, and abnormalities will bring about acute urinary retention. Bladder has two important functions storage and voiding. During storage phase, the sympathetic drive (T10 L2) exerts repressive impact on the parasympathetic mediated detrusor tone and permits external anatomical sphincter (rhabdosphincter) contractions. Detrusor contraction is generally coordinated by the excitative impact of the parasympathetic nerve (S2-S4) managed by pontine urination centre within the brainstem (voiding phase).

Omer A Raheem et al, in a case report ascertained AUR in an exceedingly young man secondary to intensive purging of colon for hygiene purposes [13]

Miyazato et al. [8], in associate experimental animal model, observed the repressive role of distention of rectum on detrusor contraction in rats. The rectum was inflated by a balloon and also the bladder detrusor pressure was then measured cystometrically. This was followed by intrathecal injection of strychnine (a selective glycine receptor antagonist) or bicuculline (GABA receptor antagonist), that blocked the reflex and fixed traditional detrusor contraction. During this study, it had been illustrated that the induced rectal distention, up to $3 \mathrm{~cm} 3$, reduced bladder contraction. This study inferred the presence of an repressive recto-vesical reflex, that is controlled by the glycinergic or GABAergic mechanisms within the lumbosacral cord of rats [8].

Shafik et al. [9] afterwards developed a human based model supported on Miyazato's findings. They confirmed the presence of the recto-vesicourethral reflex. Fifteen healthy people had their rectum anaesthetized with xylocaine solution consisting of twenty cc of 2 percent xylocaine to inhibit the stretch receptors. The rectum was then distended with a balloon in increments of fifty cc to three hundred cc. The vesical and urethral pressures were obtained with catheter transducers in response to balloon distension of rectum 3 hours and twenty minutes after xylocaine administration. The procedure was then repeated using normal saline administration into rectum instead of xylocaine. During this study, distention of rectum 
up to three hundred cc was related to a major decrease within the intra-vesical pressure (mean pressure: $3.2 \pm 0.5 \mathrm{cmH} 20$; range: 1.7 to $4 \mathrm{cmH} 20$ ), whereas increasing urethral pressure (average pressure: $103.2 \pm 10.8 \mathrm{cmH} 20$; range: 87 to $126 \mathrm{cmH} 20$ ) [9].

This reflex physiological method is explained by rectal distention resulting in vesical dilatation and rise within the urethral sphincter tone facilitated by the recto-vesicourethral reflex. Therefore the recto-vesicourethral reflex acts alone to harmonize passing stool and micturition mechanisms within the traditional state. If distention of rectum occurs for prolonged time, the recto-vesicourethral reflex is over-stimulated resulting in retention of urine via considerably diminished vesical and raised urethral sphincter pressure. The clinical significance of such reflex could also be manifested in patients with severe constipation [9]. Injury to the pelvic nerve following anorectal surgery can even cause dysfunctional discharge of urine [10].

Godec antecedently recorded the event of acute urinary retention following anal dilatation created by homosexual activity in young males [11]. He afterwards designed an experimental human study to gauge the impact of anal dilatation on dysfunction of bladder supported his observations [12]. The cystometrical measurement of bladder pressure was done in 5 individuals with significant urgency and urge incontinence. This showed detrusor over activity and a mean bladder capacity of eighty six cc. Anus was dilated from $3.5 \mathrm{~cm}$ to five $\mathrm{cm}$ that raised bladder capability to a mean value of 406 cc on cystometrogram. This shows that mechanical stretch stimulation of the anal region will generate reflex bladder inhibition [12].

\section{Conclusion}

Severe dysentery resulting in rectal dilatation appears to induce diminished vesical, but raised urethral sphincter tone, an impact that is presumably mediated through a reflex referred to as "recto-vesicourethral reflex." This reflex is seemingly induced at defecation to abort coincidental urination. The happening of acute urinary retention followed by severe dysentery in a young man is extraordinarily rare. This case report highlights the importance of considering the likelihood of such diagnosis when examining a young patient with acute urinary retention. Appropriate and elaborate history and clinical examinations are mandatory to avoid inappropriate management. Restoration of traditional urination is achieved after minimal intervention.

\section{References}

[1]. Clark LE, Dipalma JA. Safety issues regarding colonic cleansing for diagnostic and surgical procedures. Drug Saf. 2004; 27:1235-1242. doi: 10.2165/00002018-200427150-00006. [PubMed]

[2]. Emberton M, Anson K. Acute urinary retention in men: an age old problem. BMJ. 1999; 318:921925. [PMC free article] [PubMed]

[3]. Edis RH. Retention of urine and sacral paraesthesia in anogenital herpes simplex infection. Clin Exp Neurol. 1981; 18:152-155. [PubMed]

[4]. Godec CJ. Acute urinary retention in young homosexuals. Urology. 1979; 14 doi: 10.1016/00904295(79)90528-4. [PubMed]

[5]. Godec CJ, Cass AS, Ruiz E. Another aspect of acute urinary retention in young patients. Ann Emerg Med. 1982; 11:471-474. doi: 10.1016/S0196-0644(82)80064-4. [PubMed]

[6]. Hussain IF, Taylor W, Mundy AR, Fowler CJ. Acute urinary retention: an unusual presentation of a spinal arteriovenous malformation. BJU. 1999; 83:1079-1080. doi: 10.1046/j.1464410x.1999.00136.x. [PubMed]

[7]. Miyazato M, Sugaya K, Nishijima S, Ashitomi K, Ohyama C, Ogawa Y. Rectal distention inhibits bladder activity via glycinergic and gabaergic mechanisms in rats. J Urol. 2004; 171:1353-1356. doi: 10.1097/01.ju.0000099840.09816.22. [PubMed]

[8]. Mosiello G, Gatti C, De Gennaro M, Capitanucci ML, Silveri M, Inserra A, Milano GM, De Laurentis C, Boglino C. Neurovesical dysfunction in children after treating pelvic neoplasms. BJU Int. 2003; 92:289-292. doi: 10.1046/j.1464-410X.2003.04326.x. [PubMed] 
Texila International Journal of Medicine

Volume 5, Issue 1, Jun 2017

[9]. Omer A Raheem, Ronan M Long, Rowan G Casey, Frank T D'Arcy, and Thomas H Lynch. Acute urinary retention in a young man secondary to colonic irrigation: a case report.J Med Case Reports. 2009; 3: 6757. 2009 Jun 11. doi: 10.4076/1752-1947-3-6757. [PMC]

[10]. Thomas K, Chow K, Kirby RS. Acute urinary retention: a review of the aetiology and management. Prostate Cancer Prostatic Dis. 2004; 7:32-37. doi: 10.1038/sj.pcan.4500700. [PubMed]

[11]. Shafik A, Shafik I, El-Sibai O. Effect of rectal distension on vesical motor activity in humans: the identification of the recto-vesicourethral reflex. J Spinal Cord Med. 2007;30:36-39.[PMC free article] [PubMed]

[12]. Tiguert R, Lewis RA, Gheiler EL, Tefilli MV, Gudziak MR. Case report: acute urinary retention secondary to Isaacs' syndrome. Neurourol Urodyn. 1999; 18:113-114. doi: 10.1002/(SICI)15206777(1999)18:2<113::AID-NAU6>3.0.CO;2-M. [PubMed]

[13]. Zenda T, Soma R, Muramoto H, Hayase H, Orito M, Okada T, Mabuchi H, Okino S. Acute urinary retention as an unusual manifestation of aseptic meningitis. Intern Med. 2002; 41:392-394. doi: 10.2169/internalmedicine.41.392. [PubMed] [Cross Ref] 


\title{
Predictors of Outcome in Acute Exacerbation of Chronic Obstructive Pulmonary Disease
}

\author{
Article by Suhail Neliyathodi \\ Professor and HOD, Department of Pulmonology, MES Medical College, \\ Perinthalmanna, Kerala, India \\ E-mail: sneliyath@yahoo.com
}

\begin{abstract}
Background: Exacerbations are the important cause for morbidity and mortality in COPD. The factors related to the outcome of COPD exacerbations and prognosis help to find them at risk patients.

Objectives: To find out the important factors associated with prolonged hospital stay, NIV usage and mortality following admission for COPD exacerbation.

Methods: The study is a prospective observational study involving 114 patients admitted with COPD exacerbation in MES Medical College, Kerala, India during a time period from 1st October 2013 to 31st March 2016. Disease severity accessed by FEV1, GOLD class, mMRC dyspnoea scale, $A B G$ parameters and electrolyte disturbances.

Results: Out of 114 patients' enrolled 8 patients expired during the hospital admission. 50 patients (43.9\%) had prolonged hospital stay ( $>5$ days) and the factors associated with it are low FEV1, higher respiratory rate and high blood urea level. 24 (38.1\%) of the 63 patients on NIV had prolonged NIV usage ( $>5$ days). Serum potassium value $<4$ is the only factor associated with prolonged NIV usage. Of 74 patients followed up for 3 months 19 (25.7\%) expired during the period. FEV1<36\% and Respiratory rate $>29$ are the factors independently associated with three months mortality.

Conclusions: The factors associated with in-hospital mortality are higher respiratory rate, lower FEV1 and high blood urea level. Hypokalemia is associated with prolonged days of NIV usage. Three month mortality following AECOPD is related to higher respiratory rate, and low FEV1 value. The mean cost of an AECOPD in our study is $\$ 134$.
\end{abstract}

Keywords: COPD Exacerbation, Predictors, Outcome.

\section{Introduction}

An exacerbation of COPD is an acute event characterized by worsening of patient's respiratory symptoms that is beyond normal day to day variations and leads to change in medication.1,4,5,6 Exacerbations of COPD are important events in the course of the disease because they 1) negatively affect the patient's quality of life7,8, 2) have effects on symptoms and lung function that take several weeks to recover from9, 3) accelerate the rate of decline of lung function10,11, 4) are associated with significant mortality, particularly in those requiring hospitalization and have high socioeconomic costs1,12.

Mortality following an exacerbation has been found to be related to $\mathrm{PaO} 2 / \mathrm{FiO} 2$, serum albumin, BMI, age, quality of life, specific co-morbidities, exacerbation frequency, $\mathrm{PaCO}$, LTOT use and FEV1. Angeliki M Tsimogianni et al found that length of hospital stay was related to BMI, MRC dyspnoea scale, and Long Term Oxygen Therapy (LTOT) 4. The data published by National Commission on Macroeconomics and Health in India, the per capita expenditure on COPD was Rs.42664 in 2006, and is expected to increase to Rs.62630 in 2016. Predictors of outcome following COPD exacerbations in India in general and Kerala in particular are not available. Published studies on outcome parameters other than mortality are almost nil2-5. Our study done to obtain the significance of severity of illness and the outcome in acute exacerbation of COPD. To investigate the relationship between metabolic factors and mortality in acute exacerbation of COPD. Also to obtain the cost per exacerbation. 


\section{Materials and methods}

Study design is a prospective observational study involving all patients admitted with acute exacerbation of COPD in MES Medical college Hospital, Perinthalmanna, Kerala during a period from 1st October 2013 to 31st March 2015. Diagnosis of COPD was based on GOLD COPD guideline. Inclusion Criteria- all diagnosed cases of COPD > 35 years and exacerbation according to GOLD COPD guidelines and exclusion of other significant respiratory illness. Ethical clearance was obtained from institutional ethics committee. All patients were selected after obtaining a written informed consent. Treatment is given as per GOLD COPD guidelines. Data was collected using a profoma. All patients undergo detailed clinical examination, chest x-ray, ABG analysis, spirometry (done using Vitalograph Model 6800 Pneumotrac), blood investigations including electrolytes sodium, potassium and magnesium. Spirometry will be assessed before discharge from hospital if no recent test done within six months, or in next visit. Those requiring NIV are managed in the ward unless no other indication for ICU admission.

Immediate outcome were accessed in terms of in-hospital mortality, prolonged hospital stay, NIV for $>5$ days and the need for invasive mechanical ventilation. The primary outcome is three month mortality following COPD exacerbation. The total cost of the exacerbation is assessed at the time of discharge. Three month survival is assessed by telephonic contact with the patients phone number provided. Of the total 114 cases participated in the study, 40 patients lost follow up. So three month survival is analysed with 74 patients only.

Data was entered using excel and analysis was done using SPSS version 16 . Non continuous data was expressed as frequencies, continuous variables are reported as mean plus or minus standard deviation. Study group are split on the basis of the basis of outcome. Continuous variables were analysed using students $t$ test. Baseline parameters which are significant in univariate analysis are analysed using multiple logistic regression method to determine the independent predictors of each outcome. ROC analysis was done to find out the best cut off value with maximum sensitivity and specificity for each parameter. All parameters with $\mathrm{p}<0.05$ were taken as significant. Multiple logistic regression and cox regression analysis were done to find out the independent variables which predict the three month mortality.

\section{Results}

In our study a total of 114 patients were selected as per inclusion and exclusion criteria and those who fails to give consent. Majority $(109,95.6 \%)$ of our patients belongs to male gender. The mean age of the patients in this study is 64.7 and 56 (49.1\%) belongs to the age group 6179 years. Of 114 patients studied, all patients have dyspnea and cough. Dyspnea was analysed using mMRC dyspnea scale. 32(28.1\%) of patients had grade 4 mMRC dyspnea, 48 (42.1\%) had grade 3, 30 (26.3 \%) had grade 3 and only 4 (3.5 \%) had grade 1 dyspnea. Of the total 114 patients 110 (96.5\%) patients had grade 2 or more dyspnea. The mean years of occurence of dyspnea is 10.3 years.

Table 1. Basic parameters

\begin{tabular}{|l|l|l|l|l|l|}
\hline Parameter & Mean & $\begin{array}{l}\text { Std } \\
\text { Deviation }\end{array}$ & Median & $\begin{array}{l}\text { Minim } \\
\text { um }\end{array}$ & $\begin{array}{l}\text { Maxim } \\
\text { um }\end{array}$ \\
\hline Age (in years) & 64.7 & 7.7 & & & \\
\hline Sex (male/female) & $109 / 5$ & & & & \\
\hline $\begin{array}{l}\text { Smoking } \\
\text { (never/ex/current) }\end{array}$ & $1 / 85 / 28$ & & & & \\
\hline FEV1 & $40.9 \%$ & 14.7 & 38.3 & 18 & 79 \\
\hline
\end{tabular}


Texila International Journal of Medicine Volume 5, Issue 1, Jun 2017

\begin{tabular}{|l|l|l|l|l|l|}
\hline Respiratory rate & 25.3 & 5.4 & 24.0 & 16 & 40 \\
\hline $\begin{array}{l}\text { GOLD Stage } \\
(1 / 2 / 3 / 4)\end{array}$ & $\begin{array}{l}0 / 32 / 50 / \\
32\end{array}$ & & & & \\
\hline $\begin{array}{l}\text { GOLD Class } \\
\text { (A/B/C/D) }\end{array}$ & $\begin{array}{l}1 / 10 / 2 / 1 \\
01\end{array}$ & & & & \\
\hline Hemoglobin & 13.1 & 1.7 & 13.0 & 9.4 & 17.8 \\
\hline Sodium & 135.0 & 7.2 & 136.5 & 110 & 152 \\
\hline Potassium & 4.1 & 0.7 & 4.1 & 2.9 & 5.7 \\
\hline Magnesium & 1.8 & 0.3 & 1.9 & 0.9 & 2.7 \\
\hline Urea & 33.2 & 23.8 & 27.0 & 12 & 146 \\
\hline Creatine & 0.9 & 0.4 & 0.8 & 0.5 & 3.1 \\
\hline Ph & 7.4 & 0.1 & 7.4 & 7.145 & 7.516 \\
\hline $\begin{array}{l}\text { PO2 } \\
\text { PCO2 }\end{array}$ & 70.8 & 24.9 & 68.0 & 31.7 & 212 \\
\hline $\begin{array}{l}\text { HCO3 } \\
\text { patient }\end{array}$ & 47.7 & 15.0 & 45.1 & 19.2 & 93.7 \\
\hline $\begin{array}{l}\text { Days of } \\
\text { hospitalization }\end{array}$ & 26.6 & 6.2 & 25.9 & 10 & 41.2 \\
\hline $\begin{array}{l}\text { Rost during } \\
\text { Rstay }\end{array}$ & 5.4324 .618 .0 & 835.3 & 500.0 & 0 & 7000 \\
\hline
\end{tabular}

Manual labor involving agriculture is the most common occupation accounting to $62.3 \%$ of patients. The mean year of retirement from occupation is 7.7 years. $70(60 \%)$ of patients have to stopped their work for more than 5 years. The most common co-morbidities observed in our study are systemic hypertension (10.5\%) and coronary artery disease $(9.6 \%)$. Type 2 diabetes mellitus were found in $6.1 \%$ of cases. Of the 114 patients $92(80.7 \%)$ had 1 or more hospitalizations in the previous years. 22 (19.35) had no COPD exacerbation in the past one year. Only 8 (7\%) of the 114 patients were using long term oxygen therapy. 28 (24.6\%) patients were current smokers while 85 (74.6\%) patients were ex-smokers. 90 (78.9\%). The mean BMI value in the study group is 19.8 and 55 (48.2 \%) patients have low BMI.

Table 2. Immediate mortality during admission

\begin{tabular}{|l|l|l|l|}
\hline Parameter & $\begin{array}{l}\text { Univariate } \mathrm{p} \\
\text { value }\end{array}$ & $\begin{array}{l}\text { Odds ratio/T } \\
\text { value }\end{array}$ & $\begin{array}{l}\text { Multivariate P } \\
\text { value }\end{array}$ \\
\hline $\begin{array}{l}\text { Respiratory rate }> \\
27\end{array}$ & .005 & .046 & .032 \\
\hline FEV1<35 & .035 & .101 & .245 \\
\hline Urea $>74.5$ & 0.000 & .039 & .046 \\
\hline Creatinine $>0.95$ & .067 & .248 & .917 \\
\hline Age & .414 & .819 & \\
\hline BMI & .770 & .293 & \\
\hline Sodium & .110 & 1.612 & \\
\hline
\end{tabular}




\begin{tabular}{|l|l|l|l|}
\hline Potassium & .303 & .703 & \\
\hline PaCO2 & .283 & .777 & \\
\hline Magnesium & .50 & .670 & \\
\hline $\mathrm{pH}$ & .799 & .255 & \\
\hline $\mathrm{PaO} 2$ & .924 & .328 & \\
\hline
\end{tabular}

The in-hospital mortality was 7\% (8 of 114), the factors associated with in-hospital mortality are higher respiratory rate ( $p$ value $=0.005$ ), lower FEV1 ( $p$ value $=0.035$ ) and high urea level ( $p$ value $<0.001$ ). Multivariate analysis showed that higher respiratory rate and blood urea value are the factors associated with in-hospital mortality.

Table 3. Days of hospital admission $>5$ days

\begin{tabular}{|l|l|l|l|}
\hline Parameter & $\begin{array}{l}\text { Odds ratio/t } \\
\text { Value }\end{array}$ & $\begin{array}{l}\text { Univariate } \\
\text { p value }\end{array}$ & $\begin{array}{l}\text { Multivariate P } \\
\text { value }\end{array}$ \\
\hline Respiratory rate $>23$ & 0.388 & 0.04 & .164 \\
\hline PaCO2>45.85 & 4.377 & 0.001 & .004 \\
\hline $\begin{array}{l}\text { X-RAY } \\
\text { CONSOLIDATION }\end{array}$ & 5.859 & 0.04 & .079 \\
\hline Age & .369 & .713 & \\
\hline BMI & -1.731 & .086 & \\
\hline FEV1 & -1.588 & .067 & \\
\hline Na & -1.452 & .149 & \\
\hline $\mathrm{K}$ & -1.376 & .172 & \\
\hline Mg & -1.860 & .065 & \\
\hline pH & -1.670 & .098 & \\
\hline HCO3 & 1.839 & .069 & \\
\hline Urea & 1.780 & .078 & \\
\hline Creatinine & .683 & .496 & \\
\hline
\end{tabular}

50 (43.8\%) out of 114 patients had prolonged hospital stay (>5 days). The factors associated with prolonged hospital stay are higher respiratory rate (p value 0.04 ), hypercapnia ( $p$ value 0.001 ) and chest $x$-ray features of consolidation ( $p$ value 0.04 ).

Table 4. Days on non invasive ventilation $>5$ days

\begin{tabular}{|l|l|l|}
\hline VARIABLE & T value / Exp B & P value \\
\hline Respiratory rate & -.408 & .685 \\
\hline PaCO2 & 0.083 & .934 \\
\hline FEV1 & -.213 & .832 \\
\hline HCO3 & -1.942 & .057 \\
\hline Ph & -1.275 & .207 \\
\hline Sodium & -.019 & .985 \\
\hline Potassium $<4.0$ & 4.500 & .007 \\
\hline Magnesium & -1.780 & .080 \\
\hline
\end{tabular}

63 of the 114 patients needed NIV, and the average days of NIV 5.6 days. 24 of the 63 cases had prolonged NIV ( $>5$ days). The only factor significantly associated with prolonged NIV is low potassium value ( $\mathrm{p}$ value $<0.05$ ).

12 out of 114 patients required invasive mechanical ventilation. The factors associated with the need for invasive mechanical ventilation are higher respiratory rate ( $p$ value 0.001), hypercapnia ( $\mathrm{p}$ value $<0.05$ ), hyponatremia ( $\mathrm{p}$ value $<0.044$ ), and higher values of creatine ( $\mathrm{p}$ value $<0.05)$. 
Three month mortality was accessed by telephonic interview by the observer. Of the total 114 patients selected for the study 40 patients could not be contacted. Of the 74 patients we could contact 19 (25.7\%) patients died within three months from current hospital admission. In Multiple logistic and Cox regression analysis, only FEV1 (p value $=0.031$, odds ratio 12.25, and hazard ratio 10.27) and respiratory rate ( $p$ value $=0.002$, odds ratio 10.76 and hazard ratio 5.53) are independently related to three month mortality. That is FEV1 $<365 \%$ and respiratory rate $>29$ are the independent predictors of three month mortality.

The mean cost of the exacerbation for which the patient is admitted is \$134 (Rs.8324.5), with minimum amount $\$ 87$ (Rs.5381.0)

Table 5. Results of *ROC Analysis of three months survival

\begin{tabular}{|l|l|l|l|l|l|l|}
\hline & AUC & Sensitivity & Specificity & PPV & NPV & Accuracy \\
\hline mMRC $>=4$ & 0.589 & 36.8 & 76.4 & 35.0 & 0.8 & 66.2 \\
\hline RR $>=29$ & 0.744 & 57.9 & 89.1 & 64.7 & 0.5 & 81.1 \\
\hline BMI $<=18.5$ & 0.543 & 63.2 & 54.5 & 32.4 & 0.7 & 56.8 \\
\hline FEV1 $<36 \%$ & 0.714 & 94.7 & 50.9 & 40.0 & 0.1 & 62.2 \\
\hline $\begin{array}{l}\text { Magnesium } \\
<1.8\end{array}$ & 0.551 & 63.2 & 47.3 & 29.3 & 0.8 & 51.4 \\
\hline
\end{tabular}

Table 6 Impact of Recorded Variables in Categories (from ROC* Analysis) on Three-year Mortality Using Multiple Logistic Regression Analysis and Cox Regression Analysis

\begin{tabular}{|c|c|c|c|c|}
\hline & \multicolumn{2}{|c|}{ Multiple Logistic Regression } & \multicolumn{2}{|c|}{ Cox Regression Analysis } \\
\hline & OR (95 \% CI) & $\mathrm{p}$ & HR (95 \% CI) & $\mathrm{p}$ \\
\hline $\begin{array}{l}\text { MMMRC } \\
>=4\end{array}$ & $1.1(0.28-4.25)$ & 0.894 & $1.14(0.43-3.02)$ & 0.794 \\
\hline $\mathrm{RR}>=29$ & $10.76(2.44-47.38)$ & 0.002 & $5.53(2.13-14.34)$ & 0.0004 \\
\hline $\mathrm{BMI}<=18.5$ & $2.87(0.63-13.05)$ & 0.173 & $1.6(0.57-4.49)$ & 0.372 \\
\hline FEV1 $<36 \%$ & $\begin{array}{l}12.25(1.26- \\
118.83)\end{array}$ & 0.031 & $10.27(1.32-80.11)$ & 0.026 \\
\hline $\begin{array}{l}\text { Magnesium } \\
<1.8\end{array}$ & $1.24(0.3-5.04)$ & 0.764 & $0.8(0.27-2.31)$ & 0.674 \\
\hline
\end{tabular}

Graph Showing ROC Analysis on Three-year Mortality for Respiratory Rate $>29$ and FEV1<36\% 


\section{ROC Curve}

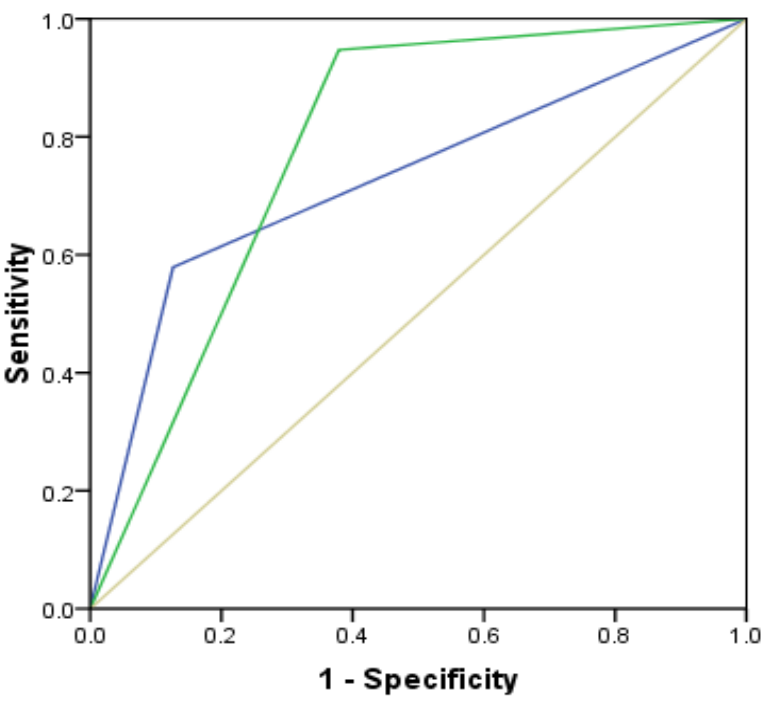

Source of the Curve

- RespiratoryRate

- FEV1

Reference Line

Diagonal segments are produced by ties

\section{Discussion}

Chronic obstructive pulmonary disease is a major cause of health care burden worldwide and the only leading cause of death that is increasing in prevalence. Acute exacerbation of COPD is a common cause of emergency department visit and hospital admission. Following an acute exacerbation majority of patients experience a temporary or permanent decrease in quality of life. More than half of the patients discharged with AECOPD often require readmission in the subsequent six months. The variability in the outcome and course of AECOPD even in patients with similar degree of pulmonary impairment renders the prediction of outcome in a given patient very difficult. Though AECOPD is an important cause of emergency department visits and hospital admission in India only very few studies were published about the outcomes and predictors of outcome in AECOPD from India, particularly from state of Kerala. This study is an observational study on outcome of AECOPD and the predictors of outcome in AECOPD.

The in-hospital mortality was 7\% (8 of 114), the factors associated with in-hospital mortality are higher respiratory rate ( $p$ value $=0.005$ ), lower FEV1 ( $p$ value $=0.035$ ) and high urea level ( $p$ value $<0.001$ ). Multivariate analysis showed that higher respiratory rate and blood urea value are the factors associated with in-hospital mortality. Study by Angeliki M Tsimogianni et al obtained the in-hospital mortality was 4.9\% (4/81 patients). Present study has slightly higher in-hospital mortality than this study, probably because in our study majority of patients were in higher Gold stage.

50 (43.8\%) out of 114 patients had prolonged hospital stay ( $>5$ days). The factors associated with prolonged hospital stay are higher respiratory rate (p value 0.04 ), hypercapnia ( $\mathrm{p}$ value 0.001 ) and chest $\mathrm{x}$-ray features of consolidation ( $\mathrm{p}$ value 0.04 ). Similar study by Angeliki M Tsimogianni et al observed that $33.33 \%$ of patients had prolonged hospital stay. The factors significantly associated with prolonged hospital stay are, BMI, MRC score, LTOT, and PaCO2. In our study there was no association between BMI, mMRC score, and LTOT with prolonged hospital stay.

63 of the 114 patients needed NIV, and the average days of NIV 5.6 days. 24 of the 63 cases had prolonged NIV ( $>5$ days). The only factor significantly associated with prolonged NIV is low potassium value ( $p$ value $<0.05$ ). That is hypokalemia is associated with prolonged NIV use. 
12 out of 114 patients required invasive mechanical ventilation. The factors associated with the need for invasive mechanical ventilation are higher respiratory rate ( $\mathrm{p}$ value o.oo1), hypercapnia ( $\mathrm{p}$ value $<0.05$ ), hyponatremia ( $\mathrm{p}$ value $<0.044$ ), and higher values of creatine ( $\mathrm{p}$ value $<0.05)$.

Of the total 114 patients selected for the study 40 patients could not be contacted. Of the 74 patients we could contact 19 (25.7\%) patients died within three months from current hospital admission. Low FEV1 (FEV1 < 36.5\%) and higher respiratory rate $>29$ ) are the independent predictors of three month mortality. Both these factors can be easily accessed for all patients. Special attention may be given to patients having these bad predictors of outcome and which may help them to recover from.

Similar study by Angeliki et al done in Greece found out that the BMI and MRC dyspnea scale are the independent predictors of three year mortality. Study by Kim S et al on Mortality after an emergency department visit for chronic obstructive pulmonary disease observed that the three year mortality is independently associated to age, specific co-morbid conditions and history of prior COPD exacerbations.

\section{CONCLUSION}

The factors associated with in-hospital mortality are higher respiratory rate, lower FEV1 and high blood urea level. Hypokalemia is associated with prolonged days of NIV usage. Three month mortality following AECOPD is related to higher respiratory rate, and low FEV1 value. The mean cost of an AECOPD in our study is \$134.

\section{References}

[1]. Burge S, Wedzicha JA. COPD exacerbations: definitions and classifications. Eur Respir J Suppl 2003; 41:46s-53s.

[2]. Celli BR, Barnes PJ. Exacerbations of chronic obstructive pulmonary disease. Eur Respir J 2007; 29:1224-38.

[3]. Chronic Obstructive Pulmonary Disease, COPD; Acute Exacerbation of Chronic Obstructive Pulmonary Disease, AECOPD; Non Invasive Ventilation, NIV; Global Initiative for Chronic Obstructive Lung Disease, GOLD; Body Mass Index, BMI; Forced Expiratory Flow in first second, FEV1; Modified Medical Research Council, mMRC ;Long Term Oxygen Therapy, LTOT ;Partial pressure of oxygen, $\mathrm{PaO} 2$;Partial pressure carbon dioxide, $\mathrm{PaCO} 2$;Bicarbonate, HCO3.

[4]. GOLD COPD-- Global strategy for Diagnosis, Management, and Prevention of Chronic Obstructive Pulmonary Disease revised 2014. http://www.goldcopd.com/

[5]. Jindal SK, Agarwal AN, Gupta D. A review of population studies from India to estimate national burden of chronic obstructive pulmonary disease and its association with smoking. Indian J Chest Dis Allied Sci. 2001;43(3):139-47

[6]. Kessler R, Stahl E, Vogelmeier C, et al. Patient understanding, detection, and experience of COPD exacerbations: an observational, interview-based study. Chest 2006; 130:133-42.

[7]. Lopez AD, Shibuya K, Rao C, et al. Chronic obstructive pulmonary disease: current burden and future projections. Eur Respir J 2006; 27:397-412.

[8]. Murthy KJ, Sastry JG. Economic burden of chronic obstructive pulmonary disease. NCMH Background Papers- Burden of Diseases in India; 2005.pp. 264-74.

[9]. Rodriguez-Rosin R. Toward a concensus definition for COPD exacerbations. Chest2000; 117:398S-401S.

[10]. Spencer S, Calverley PM, Burge PS, Jones PW. Impact of preventing exacerbations on deterioration of health status in COPD. Eur Respir J 2004; 23:698-702.

[11]. Seemungal TA, Donaldson GC, Bhowmik A, Wedzicha JA. Time course and recovery of exacerbations in patients with chronic obstructive pulmonary disease. Am J Respir Crit Care Med 2000; 161:1608-13.

[12]. Smetana MM. Preoperative pulmonary evaluation. N Engl J Med 1999; 340:937-44.

[13]. Kanner RE, Anthonisen NR, Connett JE. Lower respiratory illness promote FEV1 decline in current smokers but not ex-smokers with mild chronic obstructive pulmonary disease: results from the lung health study. Am J Respir Crit Care Med 2001; 164:358-64. 
[14]. Textbook of Pulmonary and Critical Care Medicine: First edition 2011; SK Jindal.

[15]. World health report. Geneva: World Health Organisation. Available from URL http://www.who.int/whr/2000/en/statistics.htm;2000

[16]. Wourers EF. The burden of COPD in Netherlands: results from the Confronting COPD survey. Respir Med 2003; 97 Suppl C:S51-9. 


\title{
Comparison of Accommodative Facility in Tennis Players and Non Players
}

\author{
Article by JayaRajini Vasanth ${ }^{1}$, Sharmila ${ }^{2}$ \\ ${ }^{1,2}$ Sri Ramachandra Medical College \& Research Institute, Chennai \\ E-mail: harshrajvas@yahoo.com
}

\begin{abstract}
Accommodative facility refers to the speed in which the eye is able to change focus from one distance to another. Tennis is a dynamic sport in which the targets are focused at different distances. Therefore accommodative facility in tennis players and nonplayers has been compared. Thirty -two young male experienced tennis players and thirty- two male nonplayers (did not take part in any racket sports game) were evaluated. The accommodative facility was tested with accommodative flippers (+/-2.00 sphere lenses) binocularly. The subject having 6/6 monocular and binocular near acuity with habitual refractive correction was included in the study. Nonplayers of the same age and sex were included in the study. The mean value of the accommodative facility for the players was $11.92 \mathrm{cpm}$. The mean value of accommodative facility for the nonplayers was $6.66 \mathrm{cpm}$ and the $P$ value was 0.0005 so there were high statistical significant changes between tennis players and nonplayers. This result can be used to detect sports talents and for players with reduced accommodative facility, vision therapy can be used to improve their facility of ocular accommodation
\end{abstract}

Keywords: Accommodative facility, tennis players, accommodative flippers

\section{Introduction}

Sports vision is a branch of optometry which encounters athletes' ocular health, correction management, protection. vision training to build their performance. Vision triggers the muscle of the body to respond. visual information also feed the athlete what to do, where to do and how to do. Ability to quickly respond to the visual information presented to them can differentiate between skilled and non skilled players. This was been easily defined by the legendary American Football coach, Blanton Collier (1979) who created the concept that 'eye leads the body'. ${ }^{1}$ There is an interconnection between sports, body and vision. ${ }^{2}$ All the sports game will enhance human sensory and motor systems. The eyes send visual information to the neural system, the brain analyses and unify the visual data and then feeds out motor signals to the muscles. Various sports will require various visual abilities ${ }^{3}$

According to American Optometric Association

Visual skills important for tennis

- Visual Acuity

- Peripheral Vision

- Depth Perception

- Eye Motility

- Eye-Hand/Body/Foot Coordination

- Visualization

- Speed of Recognition Time

- $\quad$ Speed of Focusing

- Ability to See in Dim Illumination

- Color Perception

- Fixation Ability

- Central/Peripheral Awareness

- Spatial localization 
Accommodation is defined as a process which the ocular system will change its refractive power to bring the object at different distances into focus. Accommodation is specified in terms of diopters (D), that is, in terms of the reciprocal of the object distance. Accommodation required at $40 \mathrm{~cm}$ is $2.50 \mathrm{D}$. The accommodative system consists of Lag of accommodation, Tonic accommodation, Relative accommodation, Accommodative facility, Convergence accommodation. The accommodative facility is the ability of the eyes to focus at different distances and in different sequences in a given period of time. Accommodative facility refers to the speed in which the refractive power of the lens will change to focus at various distances ${ }^{4}$.In any sports facility of accommodation and vergence is important which will direct the visual attention of the athlete to the targets coming from different distances ${ }^{5}$. Holland suggested that poor accommodative facility will affect depth perception and visual processing speeds ${ }^{6}$. Infacility of accommodation is the condition in which the ability to rapidly change accommodation, from far to near distance, is failing or in which a rapid change of accommodation induces symptoms such as asthenopia, headache, and blur. ${ }^{7}$ In tennis, the player needs to focus the moving ball from far to near or vice versa which literally means that accommodative demand plays a major role. Generally, the tennis player will be unable to see the junction of the fast approaching ball with the strings of the racquet. This is mainly due to our restriction inability to track fast- moving objects ${ }^{8}$

Tennis is a game that requires the player to analyze the visual data and react in milliseconds. For many years the players have been told to "watch the ball" and players who failed to do so occurs due to poor visual training. With proper vision training accommodative facility can be improved for tennis players. Gurang Shukala, Maman Paul, Sandhu Jaspal concluded that after vision training there was signification increase in accommodation in tennis players ${ }^{9}$

As a result, the visual system of the tennis players will be more developed and their visual skills will be better than nonplayers. ${ }^{10}{ }^{11}$. Therefore accommodative facility between experienced tennis players and nonpayer was compared

\section{Methods and materials}

Thirty- two players having experience of at least one year from different sports academy were randomly recruited into the study. Participation was voluntary and proper permissions were taken. The main difference between table tennis player and control group was that they don't play any sports game seriously or even as a hobby. Players who were taking any specific medications are excluded from the study.

The accommodative facility was tested with accommodative flippers (+/-2.00 sphere lenses) binocularly. A near chart held at 40 centimeters in front of the subject. He was instructed to fixate N8 row in a well illuminated room. The +2.00 sphere lenses are used to initiate the procedure. After the momentary blur the subject is asked to report when the letters sufficiently clear to permit the continuation of letter identification. No other instructions will be given. At this point the lenses will be flipped with -2.00DS replacing the +2.00DS. This constitute one cycle. The subject will be allowed for a maximum of four seconds for a given lens power. after that time lenses will be flipped. If an adequate response is not achieved in four seconds testing will be discontinued and the number of cycles completed in one minute is recorded.The subject having 6/6 monocular and binocular near acuity with habitual refractive correction was included in the study. Non- players of the same age and sex was included in the study. The results of this study were assessed using IBM.SPSS statistics software 23.0 Version. To describe about the data descriptive statistics frequency analysis, percentage analysis were used for categorical variables and the mean \& S.D was used for continuous variables. The Shapiro Wilk's test for Normality showed the data was skewed hence; to find the significant difference between the bivariate samples in Independent groups (Players and NonPlayers) the Mann-Whitney U test was used. In the above statistical tools, the probability value .05 is considered as significant level. 


\section{Results}

Sixty- four males were included in this study. In this population thirty- two were experienced players and thirty two were nonplayers. The players had a minimum experience of at least one year. Out of the thirty- two, nine players had one year of experience, four players had two years of experience, eight players had three years of experience, four players had four years of experience, four players had five years of experience, two players had six years of experience, and one player had eight years of experience. (Graph 1)

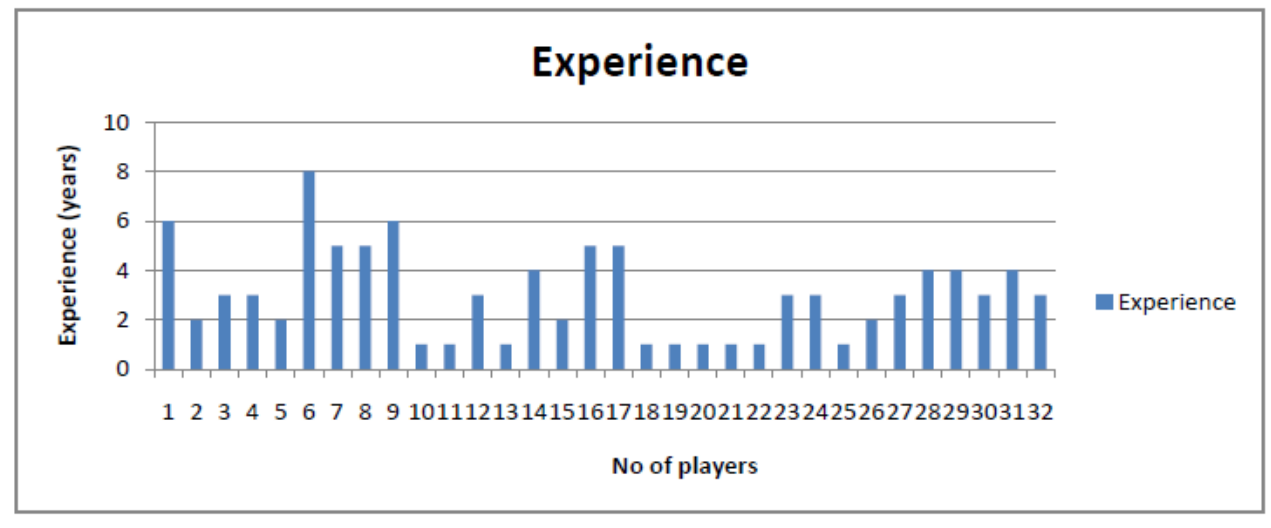

Graph 1. Experience of each player

When subjects were tested with accommodative flippers (+/- 2.00 sphere lenses) nine players had $10 \mathrm{cpm}$, one player had 10.5, four players had $11 \mathrm{cpm}$, four players had $12 \mathrm{cpm}$, four players had $12.5 \mathrm{cpm}$, four players had $13 \mathrm{cpm}$, two players had 13.5, one player had 14 cpm, two players had 15 cpm, one player had 16 cpm (Graph 2)

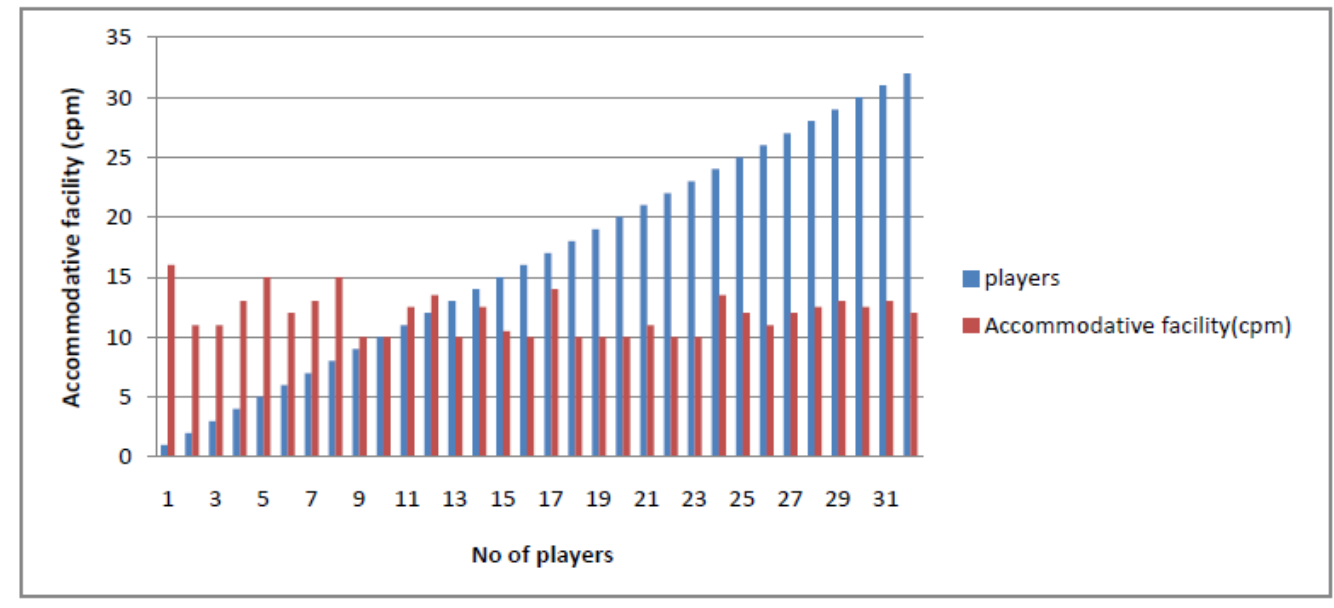

Graph 2. (Accommodative facility of each player)

When non- players were tested with accommodative facility (+/- 2.00 sphere lenses) one non-player had $2 \mathrm{cpm}$, one non- player had 3.5, three non- players had $4 \mathrm{cpm}$, two nonplayers had $4.5 \mathrm{cpm}$, three non- players had $5 \mathrm{cpm}$, three non players had $6 \mathrm{cpm}$, three nonplayers had $6.5 \mathrm{cpm}$, seven non- players had $7 \mathrm{cpm}$, two non- players had $7.5 \mathrm{cpm}$, one nonplayer had $8.5 \mathrm{cpm}$, three non- players had $8.5 \mathrm{cpm}$, three non- players had $9 \mathrm{cpm}$, and two non- players had >10 cpm.(Graph 3). 


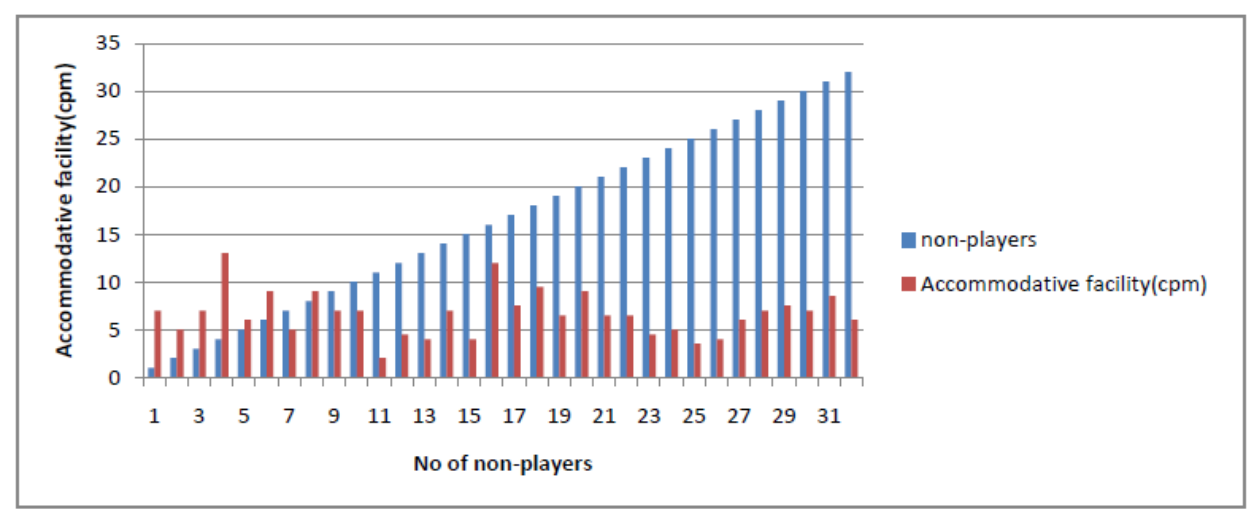

Graph 3. (Accommodative facility of non-players)

The mean value for the accommodative facility of the players obtained was 11.92 , and the mean value for accommodative facility of the non- players obtained was 6.66. In this study $\mathrm{P}<0.0005$, and there is high statistical changes between players and non- players (Table 1 )

Table 1

\begin{tabular}{|l|l|l|l|l|}
\hline \multicolumn{6}{|l|}{ Bivariate comparison by Mann-Whitney U test } \\
\hline Groups & Mean & S.D & $\begin{array}{l}\text { Z- } \\
\text { Value }\end{array}$ & P-Value \\
\hline Players & 11.92 & 1.70 & \multirow{2}{*}{6.357} & $0.0005 * *$ \\
\hline Non Players & 6.66 & 2.35 & & \\
\hline ** Highly statistical significant at P $\leq 0.01$ level \\
\hline
\end{tabular}

\section{Discussion}

As the results shows, there is a significant difference of accommodative facility between players and nonplayers. Development of accommodative facility may improve the efficiency of the visual system. Tennis sport requires speed, endurance and fast reaction time. The tennis player needs visual skills such as eye alignment for accurate fixation on the ball, eye flexibility in order to shift the focus from far and near.

(Ripoll and Latiri, 1997) Tennis player uses saccadic eye movements for fixation on the ball. Saccadic eye movements are used for rapid screening. Saccades are rapid movements of the eyes that change the point of fixation. Saccades can be evoked voluntarily but occur when the eyes are open, even fixated on a target. Vergence eye movements allow the eye to focus on the object at various distances. Suppression takes place in saccadic eye movement. While the eyes are rotating to the next fixation they are essentially turned off to prevent a blur of light and images as they move. This downtime has been called saccadic suppression, omission or visual masking.

In Tennis, the player hit the ball in 140mph which is the minimum standard speed for men. So the player needs to change in accommodation as fast as his saccadic eye movements.

There is a synergism between binocular vision, accommodation and vergence. So improving bionocular vision improves accommodative facility and anomalies of binocular vision cause anomalies of accommodation. Tennis player improves binocular vision so there is an improvement in the accommodative facility. Our results suggested that there was a significant change in the facility of ocular accommodation between the experienced tennis players and non players.

Trachtman and Kluka (1993) described a web of neurochemical relationship for vision within the whole nervous system. Also, that autonomic nervous system control of accommodation facilitates a link between central and peripheral vision. This connection enables the parallel processing necessary when both central and peripheral vision operate 
simultaneously as often they do in sports action. Moreover, they said that relaxation of the accommodative system can expand the peripheral visual field and that accommodation training can bring about changes in color perception as well as improvement in foveal fixation of the object in space.

Sensory, motor, perceptual conditions are more efficient in champions. Specific motor abilities for effective visual search must be considered for any successful player. In sports, the central vision is used to track an object, fixate on an object in space, shift focus from one object to another.

Paul Maman, Shukla Gaurang \& Sandhu J. S. concluded that after sufficient vision training there was an improvement in the accommodative facility. And also added that vision training is useful for tennis performance and also boost the performance of other racquet sports as well. The visual system can be trained specifically for different sports along with regular practice which could provide a greater success to the athlete in competition. Accommodation is controlled by an autonomic system and a recent study by Ferrauti et al showed the autonomic system to be more efficient among tennis players.

There was a high statistical change in accommodative facility between experienced tennis players and nonplayers.

\section{Conclusion}

There was a high statistical change in accommodative facility between experienced tennis players and nonplayers. This result can be used to detect sports talents and for players with reduced accommodative facility, vision therapy can be used to improve their facility of ocular accommodation. At the end, trainer should be conscious that vision is also a factor which will affect the performance of the player.

\section{Reference}

[1]. Brabenec, J., \& Stojan, S. (2006). The invisible technique: Two seconds decide the result. ITF Coaching and Sport Science Review, 38

[2]. Collier B: The eyes lead the body, optom management 15:73, 1979

[3]. Coffey B, Rrichow AW. Visual performance enhancement in sports optometry. In: Loran DF (: MacEwen 4, eds. Sports Vision. Oxford: Butterworth Heinemann, 199.5: 158-177.

[4]. Christenson, G. N., \& Winkelstein, A. M. (1988). Visual skills of athletes versus non-athletes: development of a sports vision testing battery. Journal of American Optometric Association, 59(9), 666-675.

[5]. Dogan, B. (2009) Multiple-choice reaction and visual perception in female and male elite 4 athletes. Journal of Sports Medicine and Physical Fitness, 49, 91-96

[6]. Ferrauti, A., Neumann, G., Weber, K., \& Keul, J. (2001). Urine catecholamine concentrations and psychophysical stress in elite tennis under practice and tournament conditions. The Journal of Sports Medicine and Physical Fitness, 41, 269-274.

[7]. Hitzeman, S.A. and Beckerman, SA. (1993) what the literature says about sports vision. Ed: L. Press. Optom Clin 3, 145-169.

[8]. Holland K. Training the eye on sporting success. optician 193; 30 July 16-18

[9]. Hennessey D, Iosue RA, Rouse MW. (1984) Relation of symptoms to accommodative infacility of school-aged children. Am J Optom Vis Opt. 61: 177-83.

[10]. Paul Maman, Shukla Gaurang \& Sandhu J. S. The effect of vision training on performance in tennis players. Serb J Sports Sci 5(1): 11-16

[11]. Ripoll, H. and Latiri, I. (1997) Effect of expertise on coincident-timing accuracy in a fast ball game. Journal of Sports Science 15, 573-580.

[12]. Trachtman, J.N. and Kluka, D.A. (1993) 'Future trends in vision as they relate to peak performance in sport', International Journal of Sports Vision, 1-7.

[13]. Wick B, Hall P. (1987) Relation among accommodative facility, lag, and amplitudes in elementary school children. Am J Optom Physiol Opt. Aug; 64(8): 593-8. 


\section{TEX IL $\Lambda$ \\ JOURNAL}

\section{Texila American University Ltd,}

Unit T 1/F, Mau Lam Comm Building,

16-18 Mau Lam Street, Jordan, Kowloon, Hong Kong.

E-mail: ejournal.assist@tau.edu.org Skype: texila.aco32

Whatsapp: +918056580933 